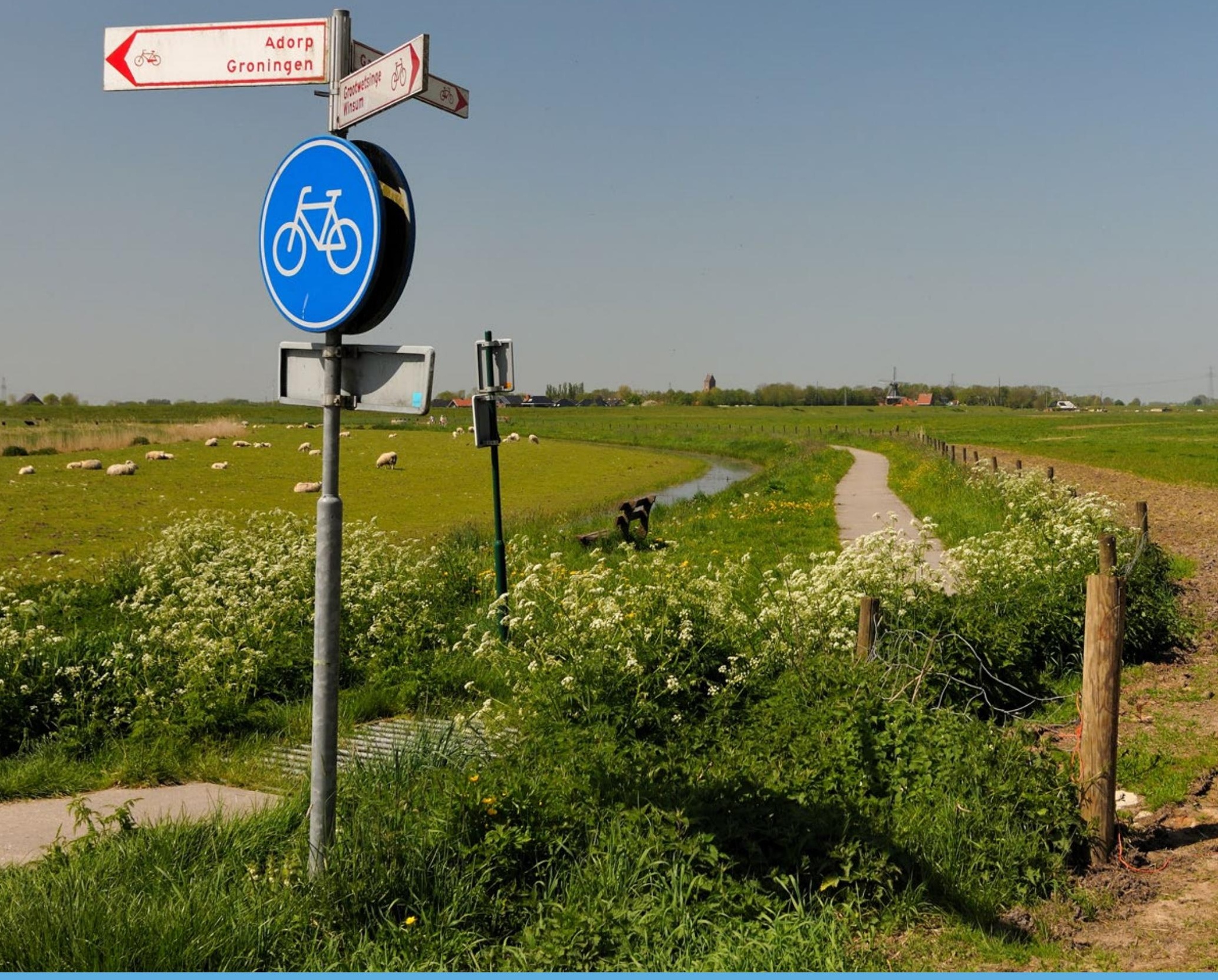

\title{
Natuur en landschap in de Omgevingswet
}



Natuur- en landschap in de Omgevingswet 
Dit Technical report is gemaakt conform het Kwaliteitsmanagementsysteem (KMS) van de unit Wettelijke Onderzoekstaken Natuur \& Milieu, onderdeel van Wageningen University \& Research.

De WOT Natuur \& Milieu voert wettelijke onderzoekstaken uit op het beleidsterrein natuur en milieu. Deze taken worden uitgevoerd om een wettelijke verantwoordelijkheid van de Minister van Landbouw, Natuur en Voedselkwaliteit (LNV) te ondersteunen. We zorgen voor rapportages en data voor (inter)nationale verplichtingen op het gebied van agromilieu, biodiversiteit en bodeminformatie, en werken mee aan producten van het Planbureau voor de Leefomgeving zoals de Balans van de Leefomgeving.

\section{Disclaimer WOt-publicaties}

De reeks 'WOt-technical reports' bevat onderzoeksresultaten van projecten die kennisorganisaties voor de unit Wettelijke Onderzoekstaken Natuur \& Milieu hebben uitgevoerd.

Dit onderzoek is uitgevoerd in opdracht van het Planbureau voor de Leefomgeving (PBL). Het PBL is een inhoudelijk onafhankelijk onderzoeksinstituut op het gebied van milieu, natuur en ruimte, zoals gewaarborgd in de Aanwijzingen voor de Planbureaus, Staatscourant 3200, 21 februari 2012.

Dit onderzoeksrapport draagt bij aan de kennis die verwerkt wordt in meer beleidsgerichte publicaties zoals Natuurverkenning, Balans van de Leefomgeving en andere thematische verkenningen.

Het onderzoek is gefinancierd door het ministerie van Landbouw, Natuur en Voedselkwaliteit (LNV). 


\section{Natuur- en landschap in de Omgevingswet}

F.H. Kistenkas, W. Nieuwenhuizen, D.A. Kamphorst \& M.E.A. Broekmeyer

ISSN 2352-2739

DOI: $10.18174 / 465835$ 


\section{Referaat}

Kistenkas, F.H., W. Nieuwenhuizen, D.A. Kamphorst \& M.E.A. Broekmeyer (2018). Natuur en landschap in de Omgevingswet. Wettelijke Onderzoekstaken Natuur \& Milieu, WOt-technical report 24. 46 blz.; 5 fig.; 31 ref; 1 Bijlage.

In 2021 wordt de nieuwe Omgevingswet ingevoerd. De exacte consequenties voor de praktijk van natuurbescherming zijn nog niet goed te overzien omdat nog niet alle teksten definitief zijn. Daarnaast is het onduidelijk of de stelselherziening van het omgevingsrecht met de Omgevingswet tot betere besluitvorming zal leiden voor de dossiers natuur en landschap. Eén van de redenen is dat er geen landelijk kader is voor integrale afweging. Wel is al duidelijk dat de omzetting van oude naar nieuwe wetgeving niet geheel beleidsneutraal verloopt. Hierdoor wordt bijvoorbeeld de bescherming van het nationaal natuurnetwerk minder sterk.

Trefwoorden: Omgevingswet, natuur, landschap, ruimtelijke ordening, wetgeving

\section{Abstract}

Kistenkas, F.H., W. Nieuwenhuizen, D.A. Kamphorst \& M.E.A. Broekmeyer (2018). Nature and landscape in the Environment and Planning Act. Statutory Research Tasks Unit for Nature \& the Environment (WOT Natuur \& Milieu), Wot-technical report 133. 46 pp; 5 fig.; 31 ref.; 1 Appendix.

The new Environment and Planning Act comes into force in 2021. The exact consequences for nature conservation cannot yet be fully ascertained because the relevant documents have not all been completed. In addition, it is not clear whether or not the reform of environmental and planning law under the Environment and Planning Act will lead to better decision making on nature and landscape. One of the reasons for this is that there is no national framework for integrated appraisal. What is clear is that the transition from the old to the new legislation will not be entirely policy neutral. For one thing, the level of protection afforded the national ecological network will be reduced.

Keywords: Environment and Planning Act, nature, landscape, land use planning, legislation

\section{(C) 2018 Wageningen Environmental Research}

Postbus 47, 6700 AA Wageningen

Tel: (0317) 4807 00; e-mail: wim.nieuwenhuizen@wur.nl

De reeks WOt-technical reports is een uitgave van de unit Wettelijke Onderzoekstaken Natuur \& Milieu, onderdeel van Wageningen University \& Research. Dit technical report is verkrijgbaar bij het secretariaat. De publicatie is ook te downloaden via www.wur.nl/wotnatuurenmilieu.

Wettelijke Onderzoekstaken Natuur \& Milieu, Postbus 47, 6700 AA Wageningen

Tel: (0317) 4854 71; e-mail: info.wnm@wur.nl; Internet: www.wur.nl/wotnatuurenmilieu.

Alle rechten voorbehouden. Niets uit deze uitgave mag worden verveelvoudigd en/of openbaar gemaakt door middel van druk, fotokopie, microfilm of op welke andere wijze ook zonder voorafgaande schriftelijke toestemming van de uitgever. De uitgever aanvaardt geen aansprakelijkheid voor eventuele schade voortvloeiend uit het gebruik van de resultaten van dit onderzoek of de toepassing van de adviezen. 


\section{Woord vooraf}

Natuur en landschap zijn belangrijke thema's in de studies van het Planbureau voor de Leefomgeving (PBL). Bij onderzoeken naar deze thema's komt de rol van het Nederlandse omgevingsrecht in de sturing op natuur en landschapsdoelen vaak aan bod. Met de aanstaande komst van de Omgevingswet veranderen deze spelregels grondig. Vandaar dat het PBL aan Wageningen Environmental Research heeft gevraagd in beeld te brengen wat het nieuwe stelsel in potentie betekent voor de bescherming en ontwikkeling van natuur en landschap. Dit rapport geeft daar invulling aan, met de kanttekening dat vooral voor natuur de raamwet nog niet volledig is ingevuld, waardoor de gevolgen voor natuur nog niet volledig in beeld gebracht kon worden.

Wij bedanken Alexandra Tisma van het PBL en Joep Dirkx van de Wettelijke Onderzoektaken Natuur \& Milieu voor hun inbreng in dit project.

Fred Kistenkas, Wim Nieuwenhuizen, Dana Kamphorst \& Mirjam Broekmeyer 



\section{Inhoud}

Woord vooraf

Samenvatting

$1 \quad$ Inleiding

2 De Omgevingswet

$2.1 \quad$ Aanleiding van de stelselherziening Omgevingswet 13

2.2 Doelstelling Omgevingswet $\quad 13$

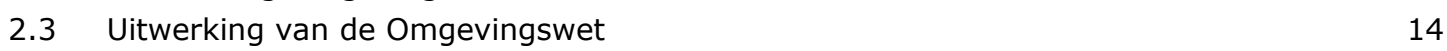

2.4 Mogelijkheden voor bescherming natuur en landschap 16

$\begin{array}{lr}2.5 & \text { Nieuwe begrippen: omgevingswaarde en instructieregels } \\ 2.6\end{array}$

$\begin{array}{ll}2.6 & \text { Participatie } \\ 2.7 & 18\end{array}$

$\begin{array}{ll}2.7 & \text { Afwegingsruimte } \\ 2.8 & 19\end{array}$

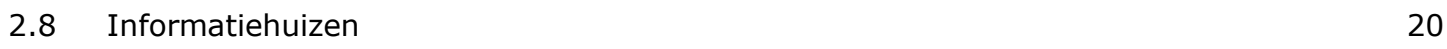

$3 \quad$ Natur in de Omgevingswet $\quad 23$

$\begin{array}{lll}3.1 & \text { Plaats van natuur in de wet } & 23\end{array}$

$\begin{array}{lll}3.2 & \text { Betekenis omgevingswet voor natuur } & 23\end{array}$

$\begin{array}{lll}3.3 & \text { Natuur- en omgevingswaarden } & 26\end{array}$

$\begin{array}{lll}3.4 & \text { Beleidsneutrale omzetting } & 26\end{array}$

4 Landschap en cultuurhistorie in de Omgevingswet $\quad 29$

$\begin{array}{lll}4.1 & \text { Plaats van landschap in de Omgevingswet } & 29\end{array}$

$\begin{array}{lll}4.2 & \text { Omgevingswaarden } & 31\end{array}$

$\begin{array}{lll}4.3 & \text { Instructieregels } & 31\end{array}$

$\begin{array}{lll}4.4 & \text { Unesco-werelderfgoed } & 32\end{array}$

$\begin{array}{lll}4.5 & \text { Overig landschapsrecht } & 32\end{array}$

4.6 Illustratie Steenwijkerland: uitwerking van landschapsbeleid 33

$5 \quad$ Boodschappen voor natuur en landschap $\quad 35$

$\begin{array}{lll}5.1 & \text { Natuurwetgeving verbrokkelt } & 35\end{array}$

$\begin{array}{lll}5.2 & \text { Beleidsafzwakking Natuurnetwerk Nederland } & 35\end{array}$

$\begin{array}{lll}5.3 & \text { Eenvoudig beter en duurzamer? } & 36\end{array}$

$\begin{array}{lll}5.4 & \text { Meer of juist minder participatie voor natuur en landschap } & 37\end{array}$

$\begin{array}{lr}\text { Literatuur } & 39\end{array}$

$\begin{array}{lr}\text { Verantwoording } & 41\end{array}$

Bijlage $1 \quad$ PBL-rapport omgevingswet - Folkert en Diederen, 2013 



\section{Samenvatting}

De Omgevingswet treedt op 1 januari 2021 in werking. De raamwet is al in 2016 in het Staatsblad gepubliceerd. Bij de Omgevingswet hoort een uitvoeringsregelgeving in de vorm van Algemene Maatregelen van Bestuur. Met de wet wil het kabinet de verschillende plannen voor ruimtelijke ordening, milieu en natuur beter op elkaar afstemmen, duurzame projecten (zoals windmolenparken) stimuleren en gemeenten, provincies en waterschappen meer ruimte geven. Zo kunnen zij hun omgevingsbeleid afstemmen op hun eigen behoeften en doelstellingen.

Verder biedt de wet meer ruimte voor particuliere ideeën. Dit komt doordat er meer algemene regels gelden in plaats van gedetailleerde vergunningen. Het doel staat voorop en niet het middel om er te komen. De houding bij het beoordelen van plannen is 'ja mits' in plaats van 'nee tenzij'. Zo ontstaat ruimte voor bijvoorbeeld bedrijven en organisaties om met ideeën te komen".

De Omgevingswet kent, net als de huidige Wet ruimtelijke ordening (Wro), een sterk decentralistisch uitgangspunt. De uitoefening van taken en bevoegdheden wordt overgelaten aan gemeenten, tenzij daarover andere regels zijn gesteld. De wet bevat evenwel wederom verschillende instrumenten voor de hogere overheidslagen van Rijk en provincie om invloed op die gemeentelijke besluitvorming uit te oefenen.

De exacte consequenties voor de praktijk van natuurbescherming zijn nog niet goed te overzien. Reden is dat de artikelen vanuit de Wet natuurbescherming deels worden opgenomen in de Omgevingswet en deels in onderliggende Besluiten. Omdat de parlementaire behandeling van de Aanvullingswet natuur (waar de Natura 2000-gebiedsbescherming, de soortenbescherming en bosbescherming in terecht gaan komen), en de bijbehorende uitvoeringsbesluiten, nog moet plaatsvinden, is het lastig de natuur- en landschapsbescherming nu al in zijn geheel in beeld te krijgen.

De Memorie van Toelichting Aanvullingswet natuur vermeldt dat de Wet natuurbescherming en alle daarin opgenomen normen en instrumenten ongewijzigd (beleidsneutraal) zullen worden gecontinueerd in de Omgevingswet en bijbehorende Algemene Maatregelen van Bestuur (AMvB) en dat geen afbreuk wordt gedaan aan het beschermingsniveau. De vraag is of dit het geval is. In de Omgevingswet en alle onderliggende instrumenten, worden de goed gestructureerde artikelen van de Wet natuurbescherming uiteen getrokken. De bepalingen kunnen terecht komen in de Omgevingswet zelf, in het Besluit algemene regels, in het Besluit kwaliteit leefomgeving (Bkl), in de Aanvullingswet natuur, in het Aanvullingsbesluit natuur en in de Aanvullingsregeling natuur. Dus ook de Aanvullingswet natuur is kaderstellend, omdat inhoudelijke normen in de uitvoeringsregelgeving zullen komen, maar de ontwerpteksten voor deze laatst twee ontbreken nog. Hierdoor ontbreekt het aan een overzicht van de uiteindelijke uitwerking. Hierdoor kan ook (nog) niet goed worden aangegeven of sprake zal zijn van een beleidsneutrale omzetting.

In elk geval is duidelijk dat de bescherming van het Natuurnetwerk Nederland (NNN) afgezwakt wordt. In het definitieve Besluit kwaliteit leefomgeving. In de huidige situatie geldt een redelijk streng nee, tenzij-regime, een soort habitattoets light: de wezenlijke kenmerken en waarden (de WKWs) van het gebied mogen niet significant worden aangetast, tenzij er geen alternatieven zijn, er sprake is van een groot openbaar belang en er compensatie plaatsvindt. Dat nee, tenzij-regime wordt in het Bkl echter niet meer genoemd. Ook de alternatieventoets en dat groot-openbare belang vinden we niet meer terug. Provincies zijn alleen nog maar verplicht om de begrenzing en de WKWs vast te stellen en voor natuurcompensatie te zorgen.

Provincies krijgen daardoor meer vrijheid om hun NNN-toets in te richten. Het zou zelfs kunnen verworden tot een zwakkere ja, mits-toets. Het enige dat geëist wordt van het provinciale beschermingsregime is dat de regels verzekeren dat de kwaliteit en oppervlakte van het NNN niet 
achteruit gaan en dat nadelige gevolgen tijdig gecompenseerd worden. Dat is minder dan wat nu geëist wordt. Het kan gaan betekenen dat twaalf provincies het elk weer anders gaan doen en ook iedere vier jaar na politieke wisselingen in provinciale staten en gedeputeerde staten veel ruimte hebben voor veranderingen.

Het is vooralsnog onduidelijk of de stelselherziening van het omgevingsrecht met de Omgevingswet tot betere besluitvorming zal leiden voor de dossiers natuur en landschap. Eén van de redenen is dat er geen landelijk kader is voor integrale afweging. Een integrale afweging vindt plaats op decentraal niveau en is mede gebaseerd op door provincie of gemeente vast te leggen omgevingswaarden. Zolang deze omgevingswaarden niet bekend zijn, is niet aan te geven hoe de integrale afweging uitpakt voor natuur en landschap. Feit is dat een deel van de in de Omgevingswet opgaande wetten uit de aard der zaak het eigen, sectorale afwegingskader behoudt. Bovendien is de Omgevingswet een raamwet, waarbij veel uitwerkingen plaatsvinden in de vier onderliggende besluiten/AMvB's. Dit maakt de uitwerking in de praktijk toch (weer) complex. Al met al is hierdoor onduidelijk hoeveel ruimte geboden wordt aan een duurzame afweging.

Voor participatie van belanghebbenden onder de Omgevingswet is een tegenstelling zichtbaar tussen hetgeen de wet beoogd (meer participatie) en hetgeen deskundigen voorzien. De vraag is hoe stakeholders betrokken worden bij de dossiers natuur en landschap. In de praktijk lijkt het dat provincies bij het opstellen van natuurvisies de verschillende belangengroepen betrekken via groene tafels, manifestpartners etc. Voor burgers wordt het lastiger om bij de rechter hun gelijk te halen: ten eerste kan men alleen bezwaar en beroep instellen als men belanghebbende is, met de invoering van het relativiteitsbeginsel in het bestuursrecht. Hiermee moet men belanghebbende zijn wil men kunnen appelleren tegen een besluit. Hiermee is de gang naar de rechter ingeperkt voor bijvoorbeeld natuuren milieuorganisaties die in het algemeen belang opereren. Ten tweede worden steeds meer activiteiten gereguleerd via algemene regels in plaats van via toetsing en vergunningverlening. Hiermee, verdwijnt de mogelijkheid om bezwaar en beroep aan te tekenen en verdwijnt dus de (bestuursrechtelijke) rechtsbescherming. 


\section{$1 \quad$ Inleiding}

\section{Achtergrond}

Met dit project wordt een eerste overzicht gegeven van de wijze waarop de thema's natuur en landschap zijn uitgewerkt in de Omgevingswet, die op 1 januari 2021 in werking zal treden.

In 2013 heeft het Planbureau voor de Leefomgeving (PBL) het effect van de Omgevingswet op natuur en landschap beschreven op basis van het toen voorliggende wetsontwerp (Folkert en Diederen, 2013 - zie bijlage 1). Het was op dat moment nog niet duidelijk wat de Omgevingswet precies gaat betekenen voor natuur en landschap en hoe de wetgeving de ambitie uit de Rijksnatuurvisie om natuurcombinaties te realiseren beïnvloedt. Het PBL wil bij het inwerkingtreden van de wet in 2021 graag de effecten van de wet en de verder uitgewerkte integratie van verschillende beleidsterreinen daarin, zoals natuur en landschap, kunnen beoordelen.

De Omgevingswet is op 23 maart 2016 in het Staatsblad gepubliceerd ${ }^{1}$. Bij de Omgevingswet hoort een uitvoeringsregelgeving in de vorm van Algemene Maatregelen van Bestuur (AMvB). Op 3 juli 2018 zijn deze besluiten openbaar gemaakt ${ }^{2}$. De wet werkt door in vier Algemene Maatregelen van Bestuur:

- Besluit activiteiten leefomgeving (Bal);

- Besluit bouwwerken leefomgeving (Bbl);

- Besluit kwaliteit leefomgeving (Bkl);

- Omgevingsbesluit (Ob).

Bovendien is op 3 juli 2018 de Aanvullingswet natuur ter consultatie gepubliceerd. Hoewel in de Omgevingswet een aantal bepalingen over natuur en landschap zijn opgenomen, werd besloten om het onderwerp natuur deels in een aanvullingswet natuur te regelen. Hiervoor is gekozen omdat "ten tijde van de indiening van het wetsvoorstel de parlementaire behandeling van de Wet natuurbescherming nog niet was afgerond en het onwenselijk was dat de herziening van de natuurbeschermings-wetgeving vertraging op zou lopen door de Omgevingswet" (VNG, 2018). Bij de Aanvullingswet natuur komen ook aanvullingsbesluiten en aanvullingsregelingen, die de doorwerking in de vier AMvB's regelen. Het Aanvullingsbesluit natuur en de Aanvullingsregeling natuur moeten nog gepubliceerd worden. Dat betekent dat de theoretische gevolgen voor natuur en landschap nog niet geheel inzichtelijk zijn, laat staan de gevolgen in de praktijk.

In dit rapport doen we verslag van de manier waarop natuur en landschap worden ondergebracht in de nieuwe wet, tot de huidige stand van zaken, en doen een inschatting wat dit mogelijk voor natuur en landschap kan betekenen. We zijn uitgegaan van de volgende onderzoeksvraag:

- Op welke manier zijn natuur en landschap ondergebracht in de nieuwe Omgevingswet en de daarbij behorende AMvB's en wat kan dit mogelijk voor natuur en landschap betekenen?

\section{Aanpak}

Dit onderzoek had een looptijd van 2017 en 2018. In beide jaren zijn de ontwikkelingen met betrekking tot de Omgevingswet bijgehouden en geanalyseerd in dit rapport.

Bij het onderzoek zijn de volgende bronnen gebruikt:

- De Omgevingswet, zoals gepubliceerd in het Staatsblad op 23 maart 2016;

- De Memorie van Toelichting op de Omgevingswet, Tweede Kamer, vergaderjaar 2013-2014, 33 962, nr. 3;

- Het Besluit kwaliteit leefomgeving (Bkl) 2018 (Staatsblad 2018, nr. 292), inclusief Nota van Toelichting en artikelsgewijze toelichting;

\footnotetext{
${ }^{1}$ Wet van 23 maart 2016, houdende regels over het beschermen en benutten van de fysieke leefomgeving (Omgevingswet)

${ }^{2}$ https://www.omgevingswetportaal.nl/actueel/nieuws/2018/07/03/belangrijke-stap-naar-eenvoudiger-en-beteromgevingsrecht
} 
- Het Omgevingsbesluit 2018, inclusief Nota van Toelichting en artikelsgewijze toelichting;

- Bijlage ${ }^{3}$ bij Kamerbrief met aanvullende informatie AMvB's Omgevingswet d.d. 10 oktober 2016;

- Algemene Maatregelen van Bestuur (AMvB's) (3 juli 2018);

- Aanvullingswet natuur (consultatie-versie) 3 juli 2018.

\section{Leeswijzer}

In hoofdstuk 2 wordt de omgevingswet geïntroduceerd en staan de uitgangspunten, begrippen en instrumenten van de omgevingswet beschreven. In hoofdstuk 3 wordt ingegaan op de bepalingen voor natuur, en wat er, voor zover nu te overzien, gaat veranderen ten opzichte van de Natuurbeschermingswet. Ook wordt ingegaan op de gevolgen van de Aanvullingswet natuur bij de Omgevingswet, waarin veel inhoudelijke bepalingen van de wet natuurbescherming landen. In hoofdstuk 4 gaan we in op de bepalingen voor landschap. In hoofdstuk 5 vatten we samen wat de gevolgen van de Omgevingswet zijn voor natuur en landschap.

\footnotetext{
${ }^{3}$ Bijlage 1. Vergelijking normhoogtes BkI milieudomein en Bijlage 2. Decentrale omgevingswaarden
} 


\section{De Omgevingswet}

\subsection{Aanleiding van de stelselherziening Omgevingswet}

\section{Uitgangspunten van de Omgevingswet}

Met de nieuwe Omgevingswet wil het kabinet ${ }^{4}$ :

- "De verschillende plannen voor ruimtelijke ordening, milieu en natuur beter op elkaar afstemmen;

- Duurzame projecten (zoals windmolenparken) stimuleren;

- Gemeenten, provincies en waterschappen meer ruimte geven. Zo kunnen zij hun omgevingsbeleid afstemmen op hun eigen behoeften en doelstellingen.

Verder biedt de wet meer ruimte voor particuliere ideeën. Dit komt doordat er meer algemene regels gelden, in plaats van gedetailleerde vergunningen. Het doel staat voorop en niet het middel om er te komen. De houding bij het beoordelen van plannen is 'ja mits' in plaats van 'nee tenzij'. Zo ontstaat ruimte voor bijvoorbeeld bedrijven en organisaties om met ideeën te komen" .

(https://www.rijksoverheid.nl/onderwerpen/omgevingswet/inhoud/vernieuwing-omgevingsrecht).

\section{Omgevingswet vereenvoudigt en bundelt omgevingsrecht ${ }^{4}$}

Het omgevingsrecht bestaat uit tientallen wetten en honderden regelingen voor ruimte, wonen, infrastructuur, milieu, natuur en water. Zij hebben allemaal hun eigen uitgangspunten, werkwijzen en eisen. De wetgeving is daardoor te ingewikkeld geworden voor de mensen die ermee werken. Daardoor duurt het bijvoorbeeld langer voordat een project kan starten.

In de Omgevingswet worden 26 huidige wetten gebundeld, samen met 120 Algemene Maatregelen van Bestuur en 120 Ministeriële Regelingen. De Omgevingswet zelf kent 349 artikelen en vier uitvoeringsregelingen (Algemene Maatregelen van Bestuur) en circa 10 Ministeriele Regelingen (Ministerie van I\&M, juni 2014).

\subsection{Doelstelling Omgevingswet}

De aanleiding voor de stelselherziening komt terug in de twee primaire doelstellingen van de Omgevingswet, zoals verwoord in artikel 1.3:

"Deze wet is, met het oog op duurzame ontwikkeling, de bewoonbaarheid van het land en de bescherming en verbetering van het leefmilieu, gericht op het in onderlinge samenhang:

a. Bereiken en in stand houden van een veilige en gezonde fysieke leefomgeving en een goede omgevingskwaliteit, en

b. Doelmatig beheren, gebruiken en ontwikkelen van de fysieke leefomgeving ter vervulling van maatschappelijke behoeften."

Twee doelstelling waar traditioneel een spanning op zit en die tegenstrijdig aan elkaar kunnen zijn. Tot de fysieke leefomgeving behoren in ieder geval (zie artikel 1.2 Omgevingswet): bouwwerken, infrastructuur, watersystemen, water, bodem, lucht, landschappen, natuur, cultureel erfgoed en werelderfgoed. De wet beschrijft het beleid voor de fysieke leefomgeving slechts op hoofdlijnen.

De Memorie van Toelichting stelt: "Het nieuwe stelsel gaat uit van een paradigmawisseling: van bescherming van de fysieke leefomgeving via een werende benadering van activiteiten, naar een beleidscyclus waar de continue zorg voor de kwaliteit van de fysieke leefomgeving centraal staat en ruimte ontstaat voor ontwikkeling." (Ministerie van I\&M, 2017).

\footnotetext{
${ }^{4}$ Tekst geheel afkomstig van: https://www.rijksoverheid.nl/onderwerpen/omgevingswet/inhoud/vernieuwingomgevingsrecht
} 


\subsection{Uitwerking van de Omgevingswet}

\section{De AMvB's (Besluiten)}

Nadere uitwerking van de Omgevingswet vindt plaats in vier Algemene Maatregelen van Bestuur (bron: Aanbieding ontwerpbesluiten Omgevingswet 1 juli 2016). Deze AMvB's of besluiten zijn in ontwerp op 1 juli 2016 ter inzage gelegd. De hoofdpunten uit de toetsing en consultatie en de conclusies die de minister hieraan verbindt, zijn in november 2017 aan de Tweede Kamer gestuurd ${ }^{5}$. In de loop van 2017 zijn de AMvB's voorgelegd aan de Afdeling advisering van de Raad van State. Op 3 juli 2018 zijn deze besluiten openbaar gemaakt.

- Het Omgevingsbesluit richt zich tot burgers, bedrijven en overheden. Het geeft in aanvulling op de Omgevingswet onder meer aan welke procedures moeten worden doorlopen en wie het bevoegde gezag is voor vergunningverlening. Ook de regels voor milieueffectrapportage, kostenverhaal en financiële zekerheidsstelling zijn in dit ontwerpbesluit opgenomen.

- Het Besluit activiteiten leefomgeving bevat de rechtstreeks werkende regels die het Rijk stelt aan activiteiten van burgers, bedrijven of overheden in de fysieke leefomgeving. Het gaat onder meer om activiteiten die het milieu belasten, activiteiten rondom wegen en waterstaatwerken, en activiteiten die betrekking hebben op cultureel erfgoed. Het ontwerpbesluit beschrijft welke regels gelden, welke ruimte er is om af te wijken van de regels en wanneer een vergunning nodig is.

- Het Besluit bouwwerken leefomgeving stelt algemene rijksregels voor activiteiten als het in stand houden, bouwen en slopen van bouwwerken. Deze regels zijn in de praktijk met name van belang voor burgers en bedrijven.

- Het Besluit kwaliteit leefomgeving is gericht tot het bevoegd gezag. Dit ontwerpbesluit bevat de inhoudelijke normen voor gemeenten, provincies, waterschappen en het Rijk, die zijn gesteld met het oog op het realiseren van de nationale doelstellingen en het voldoen aan internationale verplichtingen. Het gaat dan om instructieregels, omgevingswaarden, beoordelingsregels voor omgevingsvergunningen en regels over monitoring en gegevensbeheer. Het BkI bereikte op 31 augustus 2018 het Staatsblad. Deze AMvB bevat regels voor het Natuurnetwerk Nederland (NNN) (zie hoofdstuk 3) en zou blijkens de aanhef van paragraaf 5.1.5 ook landschappelijke waarden beschermen. Dat laatste gebeurt evenwel niet in de wettekst zelf. Alleen het Unesco-werelderfgoed wordt in de eigenlijke wettekst beschermd (zie hoofdstuk 4).

\section{Instrumenten}

Voor de uitvoering van de Omgevingswet zijn een zestal instrumenten van belang: omgevingsvisies en -programma's, die zich richten op planning en maatregelen voor de fysieke leefomgeving; omgevingsplannen en omgevingsverordeningen, die zich richten op decentrale regelgeving en de omgevingsvergunning en het projectbesluit, die zich richten op (toetsing van) op toetsing van activiteiten.

Omgevingsvisies zijn strategische beleidsplannen voor de fysieke leefomgeving. Zij komen in de plaats van structuurvisies, natuurvisies, waterplannen, milieubeleidsplannen etc. Het opstellen van een omgevingsvisie door overheden is verplicht: volgens artikel 3.1 Omgevingswet stelt de gemeenteraad een gemeentelijke omgevingsvisie vast; Provinciale staten stellen een provinciale omgevingsvisie vast; en de minister van I\&M stelt, in overeenstemming met andere Ministers die het aangaat, een nationale omgevingsvisie vast.

In artikel 3.2 is aangeven wat in een omgevingsvisie aan bod moet komen:

- Een beschrijving van de hoofdlijnen van de kwaliteit van de fysieke leefomgeving;

- De hoofdlijnen van de voorgenomen ontwikkeling, het gebruik, het beheer, de bescherming en het behoud van het grondgebied;

- De hoofdzaken van het voor de fysieke leefomgeving te voeren integrale beleid.

\footnotetext{
${ }^{5}$ Op 18 november zijn deze resultaten consultatie en toetsing AMvB's Omgevingswet door de Minister van I\&M aan de Tweede Kamer gestuurd. Zie https://www.rijksoverheid.nl/documenten/kamerstukken/2016/11/18/resultatenconsultatie-en-toetsing-ontwerp-amvb-s-omgevingswet
} 
Een programma kan worden opgesteld door het bevoegd gezag, ter uitvoering van het beleid uit de omgevingsvisie. Een programma kan verplicht zijn op grond van Europese richtlijnen of bij dreigende overschrijding van door een bestuurslaag vastgesteld omgevingswaarden.

Een programma bevat concrete maatregelen voor het gebruik, beheer, bescherming, en behoud en ontwikkeling van de fysieke leefomgeving. Het programma gaat dus over de operationele doelen uit de omgevingsvisie.

Het omgevingsplan bundelt de huidige gemeentelijk bestemmingsplannen, kapverordening, algemene plaatselijke verordening etc. Volgens artikel 4.2 Omgevingswet bevat het omgevingsplan voor het gehele grondgebied van de gemeente een evenwichtige toedeling van functies aan locaties en andere regels die met het oog daarop nodig zijn. Het betreft dus één gebiedsdekkend plan (waar veel gemeenten momenteel binnen hun grondgebied verschillende bestemmingsplannen hebben), waar alle regels voor de fysieke leefomgeving bij elkaar zijn gebracht. Nieuw is dat gemeenten nu ook milieuregels kunnen opnemen in het plan.

De omgevingsverordening wordt opgesteld door provincies en komt in plaats van de huidige provinciale ruimtelijke verordeningen, provinciale milieuverordeningen etc. Ook hier betreft het dus één integraal plan waarin de regels over de fysieke leefomgeving bijeen worden gebracht.

Waterschappen stellen in analogie een waterschapsverordening op. Een omgevingsverordening kent drie soorten regels (Stibbe, 2015):

- Algemeen direct bindende regels (voor burgers en bedrijven);

- Omgevingswaarden (voor het uitvoerend bestuur zelf);

- Instructieregels (voor andere bestuurslagen).

In de omgevingsvergunning worden zeer veel huidige vergunningen geïntegreerd, zoals de huidige omgevingsvergunning onder de Wet algemene bepalingen omgevingsrecht (Wabo), de watervergunning onder de Waterwet, de ontgrondingenvergunning onder de Ontgrondingenwet etc. In de meeste gevallen zal de gemeenten (B\&W) bevoegd gezag zijn voor het verlenen van een omgevingsvergunning.

Een omgevingsvergunning is nodig als een activiteit (grote) gevolgen kan hebben voor de fysieke leefomgeving en/of getoetst moet worden op grond van Europeesrechtelijke verplichtingen. Met het instrument omgevingsvergunning wordt dus vooraf getoetst of een activiteit mogelijk is binnen het omgevingsplan. Omgevingsvergunningen worden aangevraagd door initiatiefnemers.

Via een decentrale afweging lijkt het mogelijk om via een omgevingsvergunning af te wijken van het omgevingsplan, mits deze afweging binnen instructieregels valt (zie paragraaf 2.4).

Een projectbesluit is van toepassing als een besluit nodig is op een activiteit die door de overheid wordt ondernomen in het kader van een publiek belang. Het projectbesluit komt in plaats van het Tracébesluit, het Rijks- of Provinciaal Inpassingsplan (RIP en PIP), coördinatieprocedures en projectprocedures. Afhankelijk van de complexiteit van het overheidsproject kan gekozen worden voor een omgevingsvergunning of een projectbesluit. In de Omgevingswet (art. 5.44 e.v. Ow) is aangegeven wanneer besluitvorming via het projectbesluit kan verlopen, zoals bijvoorbeeld bij de hoofdinfrastructuur en primaire waterkeringen (art. $5.46 \mathrm{OW}$ ).

Samenvattend: in de omgevingsvisie en programma's wordt de beleidsontwikkeling vastgelegd. De regels worden opgenomen in omgevingsplannen en omgevingsverordeningen, maar ook in Algemene rijksregels via de AMvB's. Hierin herkennen we de scheiding tussen beleid en normstelling van de Wet ruimtelijke ordening. Toestemming om af te mogen wijken van de algemene regels kan plaatsvinden via de omgevingsvergunning of via het projectbesluit.

Voor de beleidsdoorwerking zijn twee zaken van belang: de omgevingswaarde en instructieregels. 


\subsection{Mogelijkheden voor bescherming natuur en landschap}

De Omgevingswet kent, net als de huidige Wet ruimtelijke ordening (Wro), een sterk decentralistisch uitgangspunt. Ingevolge art. 2.3 lid $1 \mathrm{Ow}$ wordt de uitoefening van taken en bevoegdheden overgelaten aan de gemeente, tenzij daarover andere regels zijn gesteld. De wet bevat evenwel wederom verschillende instrumenten voor de hogere overheidslagen van Rijk en provincie om invloed op die gemeentelijke besluitvorming uit te oefenen (zie figuur 2.1). Zo kunnen zij algemene instructieregels vaststellen in respectievelijk Algemene Maatregel van Bestuur (AMvB) of provinciale omgevingsverordening. Krachtens de algemene normenhiërarchie zijn AMvB's en provinciale verordeningen hoger dan gemeentelijke (plan)regels in bijvoorbeeld omgevingsplan. Deze klassieke hiërarchische trits van Rijk-provincie-gemeente komt ook weer tot uitdrukking in art. 2.11 lid 2 Ow: in een gemeentelijk omgevingsplan kunnen geen omgevingswaarden worden vastgesteld die in strijd zijn met die uit $A M v B$ of omgevingsverordening. Er geldt dus een trits van (van hoog naar laag) AMvBprovinciale omgevingsverordening-gemeentelijk omgevingsplan.

Naast algemene instructieregels krijgen Rijk en provincie ook de bevoegdheid om in een concreet geval een aanwijzing te geven. Bij zo'n instructie aan een gemeente wordt een termijn gesteld waarbinnen hieraan uitvoering moet worden gegeven. Men kan deze concrete instructies vergelijken met de oude proactieve aanwijzingen. Ook de befaamde reactieve aanwijzing (RA) keert in wezen terug: de reactieve interventiebevoegdheid van art. 16.21 Ow maakt dat GS kunnen besluiten dat een onderdeel van een gemeentelijk omgevingsplan geen deel daarvan uitmaakt. De provincie kan hiervan gebruik maken als functies worden toegedeeld aan locaties die in strijd zijn met provinciaal beleid dat vooraf kenbaar is gemaakt. Dat beleid zou bijvoorbeeld kunnen staan in een omgevingsvisie, de rechtsopvolger van de (juridisch niet-bindende doch wel beleidsvoornemens bevattende) structuurvisie.

\begin{tabular}{|c|c|c|}
\hline Overheid & Wro & Ow \\
\hline Rijk & $\begin{array}{l}\text { Rijksinpassingsplan (RIP) } \\
\text { AMvB } \\
\text { Aanwijzing (proactief) } \\
\text { Structuurvisie }\end{array}$ & $\begin{array}{l}\text { Projectbesluit } \\
\text { AMvB (instructieregels) } \\
\text { Instructiebesluit } \\
\text { Omgevingsvisie }\end{array}$ \\
\hline Provincie & $\begin{array}{l}\text { Prov. inpassingsplan (PIP) } \\
\text { Prov. ruimtelijke verordening (PRV) } \\
\text { Aanwijzing (proactief) } \\
\text { Aanwijzing (reactief) } \\
\text { Structuurvisie }\end{array}$ & $\begin{array}{l}\text { Projectbesluit } \\
\text { Omgevingsverord.(instructieregels) } \\
\text { Instructiebesluit } \\
\text { Reactieve interventie } \\
\text { Omgevingsvisie }\end{array}$ \\
\hline Gemeente & $\begin{array}{l}\text { Bestemmingsplan } \\
\text { Beheersverordening } \\
\text { Structuurvisie }\end{array}$ & $\begin{array}{l}\text { Omgevingsplan } \\
\text { Omgevingsvisie }\end{array}$ \\
\hline
\end{tabular}

Figuur 2.1 De Omgevingswet biedt een aantal vergelijkbare instrumenten als de Wro, onder een andere naam (Kistenkas et al., 2017).

Het projectbes/uit komt tenslotte in de plaats van een PIP (provinciaal inpassingsplan) of een RIP (rijksinspanningsplan). Door de gemeente kan geen projectbesluit worden vastgesteld, maar door Rijk en provincie wel en het wijzigt het gemeentelijk omgevingsplan dusdanig dat het project kan worden gerealiseerd en in stand kan worden gelaten en voor zover dat in het projectbesluit uitdrukkelijk is bepaald, geldt dit besluit bovendien als omgevingsvergunning voor de voor dat project benodigde activiteiten. Daarmee keren in wezen dus veel oude Wro-instrumenten terug zij het met een iets afwijkende benaming (Kistenkas et al., 2017). 


\subsection{Nieuwe begrippen: omgevingswaarde en instructieregels}

Binnen de instrumenten uit de vorige paragraaf zijn twee nieuwe begrippen van groot belang: omgevingswaarden en instructieregels. Het zijn nieuwe begrippen, die in de praktijk van de uitvoering meer en meer gestalte zullen moeten krijgen (Bosma, 2014).

\section{Omgevingswaarde als maatstaf voor de fysieke leefomgeving}

Een omgevingswaarde is, kort gezegd, een maatstaf voor de staat of kwaliteit van de fysieke leefomgeving (dit staat vermeld in de Nota van toelichting van het $\mathrm{Bkl}$ ). Ze kan betrekking hebben op bijvoorbeeld een toelaatbare depositie van een stof of op een gewenste staat van de kwaliteit van oppervlaktewater.

Omgevingswaarden kunnen op alle drie de bestuursniveaus (Rijk, provincie of gemeente) worden vastgesteld, in resp. het Besluit kwaliteit leefomgeving; in de omgevingsverordening of in het omgevingsplan.

Omgevingswaarden zijn dus niet in de Omgevingswet zelf vastgelegd. De wet noemt alleen onderwerpen waarvoor het Rijk en de provincie omgevingswaarden móeten vaststellen. Deze onderwerpen zijn nader uitgewerkt in het Besluit kwaliteit leefomgeving:

- Het Rijk moet omgevingswaarden vaststellen voor luchtkwaliteit, de kwaliteit van het oppervlaktewater en grondwater en de kwaliteit van het zwemwater en de veiligheid van primaire waterkeringen (artikel $2.15 \mathrm{Ow}$ ).

- Provincies zijn verplicht omgevingswaarden vast te stellen voor het watersysteem (artikel 2.13 Ow).

Aanvullend op deze verplichte omgevingswaarden is het aan elke bestuurslaag zelf om te bepalen of en voor welke andere onderdelen van de fysieke leefomgeving ze aanvullende of strengere omgevingswaarden willen vaststellen. Dat geldt ook voor het Natuurnetwerk Nederland (NNN). Voor het NNN moet de provincie daarbij echter wel binnen de minimumeisen van het Bkl manoeuvreren. Ingevolge art. 7.6-7.8 Bkl zullen provincies bij of krachtens hun Omgevingsverordening de begrenzing, wezenlijke kenmerken en waarden (WKWs) en het beschermingsregime moeten vaststellen (zie hierover paragraaf 5.2).

\section{Omgevingswaarde}

Omgevingswaarden kunnen door gemeente (in hun Omgevingsplan) of provincie (in hun Omgevingsverordening) of Rijk (bij AMvB) worden vastgesteld (art.2.9-2.15 Ow). Omgevingswaarden binden alleen de overheid zelf; zij moeten de maatregelen nemen om de waarden te bereiken. .

Het opnemen van omgevingswaarden heeft twee belangrijke rechtsgevolgen (Bosma, 2014; Van 't Foort en Kevelam, 2015). Ten eerste geldt een monitoringplicht voor ieder vastgestelde omgevingswaarde. Het bevoegd gezag moet dus nagaan (monitoren) of de kwaliteit van de fysieke leefomgeving e.d. waarvoor omgevingswaarden zijn vastgesteld, niet verslechtert.

Ten tweede moet als niet voldaan is/wordt aan de omgevingswaarde, het bevoegd gezag maatregelen nemen om te verzekeren dat wél aan de omgevingswaarden wordt voldaan. Deze maatregelen worden vastgelegd in een programma. Via monitoring wordt informatie verkregen over de staat van de fysieke leefomgeving. Deze resultaten kunnen ook leiden tot aanpassing van het programma waarmee de omgevingswaarde bereikt moet worden.

\section{Instructieregels: sturing decentrale overheden}

De Omgevingswet introduceert ook het begrip 'instructieregels'. De instructieregels zijn volgens de memorie van toelichting bedoeld om in te zetten op het moment dat een verantwoordelijkheid van het Rijk of een provincie moet leiden tot sturing aan of beperkingen voor andere bestuursorganen (MvT, 50). Dit houdt in dat Rijk en provincies instructieregels kunnen geven aan decentrale overheden over inhoud, toelichting of motivering van besluiten, of over de uitoefening van taken door deze overheden, 
aldus de memorie van toelichting. Dit kan via instructieregels voor een programma, een omgevingsplan, een verordening of een projectbesluit.

Als voorbeelden worden regels genoemd die nu zijn opgenomen in het Besluit algemene regels ruimtelijke ordening (Barro) voor de doorwerking van nationale ruimtelijke belangen, waaronder bijvoorbeeld ook de erfgoederen van uitzonderlijke en universele waarde (Werelderfgoederen) vallen (MvT, p.50).

\section{De vorm blijft: AMvB's en Omgevingsverordeningen}

De instructieregels kunnen een plaats krijgen in Algemene Maatregelen van Bestuur, als het de Rijksoverheid betreft. Gaat het om instructieregels die provincies aan gemeenten of waterschappen willen opleggen, dan kan dat in de Omgevingsverordening. Beide instrumenten bestaan nu ook al. Zo geeft het Rijk nu al 'instructieregels' aan provincies in het Barro over bijvoorbeeld de begrenzing en het afwegingskader rond het nationaal natuurnetwerk en de Werelderfgoederen. De provincies verplichten gemeenten op hun beurt om in hun ruimtelijk beleid (lees omgevingsplan) rekening te houden met provinciale belangen die vermeld staan in hun omgevingsverordening.

\subsection{Participatie}

In het maatschappelijk veld rond de omgevingswet worden zorgen uitgesproken over de wijze waarop de nieuwe Omgevingswet de betrokkenheid en participatie regelt van burgers, bedrijven, en maatschappelijke organisaties. Tegelijkertijd beschrijft de regering deze participatie als een belangrijke manier om besluitvorming te kunnen versnellen.

\section{Participatie volgens de wet}

In de toelichting op de wet (MvT Ow, p.14) verwijst het kabinet naar de opkomst van de energieke samenleving, zoals die door Hajer is beschreven (Hajer, 2011). Op basis van de opkomst van die energieke samenleving doet het Kabinet de aanname dat het vroeg betrekken van verschillende partijen leidt tot een snellere besluitvorming, verwijzend naar de uitspraken van de commissie Elverding (Commissie Versnelling Besluitvorming Infrastructurele Projecten, 2008).

Het betrekken van verschillende partijen wordt in het Omgevingswet samengevat onder het woord 'participatie'. In de toelichting op het ontwerp Omgevingsbesluit wordt participatie als volgt omschreven:

"Het in een vroegtijdig stadium betrekken van belanghebbenden (burgers, bedrijven, maatschappelijke organisaties en andere overheden) bij het proces van de bes/uitvorming over een project of activiteit".

De wet geeft ruimte aan overheden en initiatiefnemers om zelf invulling te geven aan het uitwerken en uitvoeren van deze participatie. Daarvoor kondigt de regering in de toelichting op het Bkl een handreiking aan die het Rijk samen met betrokken partijen, zoals VNG, IPO, Unie van waterschappen, de milieuorganisaties en VNO-NCW zal opstellen. In diezelfde toelichting omschrijft de regering de reden voor het opstellen voor deze handreiking als volgt:

"Niet alle partijen hebben de benodigde kennis in huis om een participatieproces goed vorm te geven. Gezien het belang dat de regering aan participatie hecht, zal een handreiking worden opgesteld".

\section{Initiatiefnemer moet participatie zelf vormgeven}

Een initiatiefnemer is volgens de wet verplicht om bij de aanvraag van een omgevingsvergunning gegevens aan te leveren waaruit blijkt dat participatie van derden heeft plaatsgevonden (artikel 16.55, lid $6 \mathrm{Ow}$ ). In de toelichting wordt gesteld dat hiermee een 'vroegtijdige betrokkenheid' van de belanghebbenden wordt gestimuleerd. Het wordt niet duidelijk hoe het begrip 'vroegtijdig' precies geïnterpreteerd moet worden, en ook aan de vorm worden geen eisen gesteld. 
Hoogleraar bouwrecht Nijmeijer (2015) zet vraagtekens bij deze vereiste van participatie. Hij stelt dat er ten eerste situaties zijn waarbij participatie van de omgeving een illusie is. Hij stelt daarbij de vraag welke betekenis door het bestuur en de rechter in zo'n geval moet hechten aan het niet nakomen van deze verplichting. Ten tweede stelt hij dat bij gebonden besluiten (waarbij het bevoegde bestuursorgaan moet toetsen aan wettelijke regels) de participatie louter symbolisch is. Bij open besluiten, met eigen afwegingsruimte, ziet hij niet hoe de participatie een rol kan spelen in de belangenafweging die plaats hoort te vinden door het bevoegd gezag, gezien hetgeen daarover in de Algemene Wet Bestuursrecht is geregeld in artikel 3.4, lid 1. Daar staat het volgende:

"Het bestuursorgaan weegt de rechtstreeks bij het besluit betrokken belangen af, voor zover niet uit een wettelijk voorschrift of uit de aard van de uit te oefenen bevoegdheid een beperking voortvloeit".

\section{Geen waarborgen voor integriteit informatie van initiatiefnemer}

De Omgevingswet stelt dat de initiatiefnemer degene is die belanghebbenden moet informeren. Dat betekent dat de partij die belang heeft bij de doorgang van het initiatief, tegelijkertijd informatieverstrekker is en daarmee twee petten op heeft. Dit een punt van kritiek waar het Sociaal Cultureel Planbureau (SCP) zich zorgen over maakt omdat hiermee de slager zijn eigen vlees keurt, terwijl er geen integriteitswaarborgen (Van den Broek et al., 2016). Dat komt volgens het SCP de kwaliteit met de belanghebbende niet ten goede.

\subsection{Afwegingsruimte}

\section{Voor- en achterkant}

De memorie van toelichting maakt onderscheid tussen afwegingsruimte aan de voor- en de achterkant. Met de voorkant wordt bedoeld het afwegen van belangen binnen de procedures en kaders die de Omgevingswet stelt. Daarbij zijn decentrale overheden bijvoorbeeld gebonden aan gestelde omgevingswaarden die een centrale overheid heeft gesteld. In feite is dat nu ook zo, omdat provincies en gemeenten gebonden zijn aan (landelijke) wetgeving en normstelling rond de fysieke leefomgeving, zoals voor geluid of fijnstof.

Voor omgevingswaarden kunnen harde, Europese normen gelden; of normen die zelf door bestuurslagen worden vastgesteld. Decentrale bestuurslagen mogen deze normen aanscherpen. Daarnaast kunnen bijvoorbeeld provincies in hun omgevingsverordening een onder- en een bovengrens voor een (regionale) omgevingswaarde vaststellen. In de communicatie rond de Omgevingswet worden deze mogelijkheden voor lokale afwegingsruimte voorgesteld als een mengpaneel, met regionale ruimte, maar ook met (inter)nationaal gestelde maximum of minimum waarden (zie figuur 2.2)

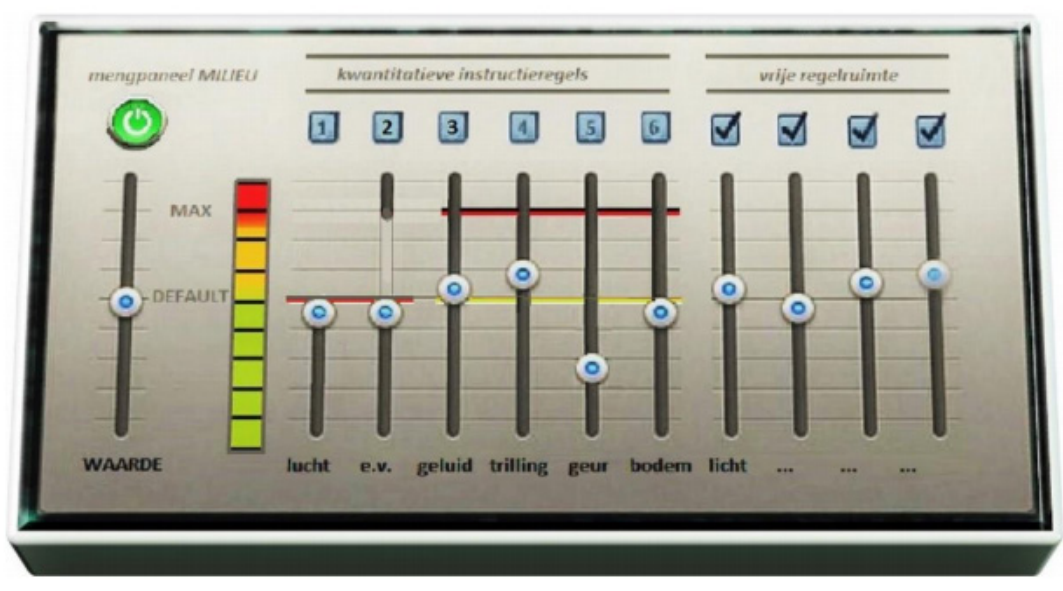

Figuur 2.2. De regionale afwegingsruimte in omgevingskwaliteit wordt afgebeeld als een 'mengpaneel' voor de kwaliteit van de fysieke leefomgeving (NVT, BKL). 


\section{Afwegingsruimte aan de achterkant}

Met afwegingsruimte aan de achterkant wordt bedoeld dat er bestuurlijke afwegingsruimte is om af te wijken van gestelde kaders. In de memorie van toelichting wordt dat als volgt geformuleerd:

"Die ruimte kan nodig zijn in verband met bijvoorbeeld bijzondere lokale situaties, complexe gebieden of gebieds-overstijgende belangen. In dit soort gevallen zal het nodig zijn dat een bestuursorgaan ontheffing van een eerder gestelde eis mag verlenen, een strengere of lichtere eis dan de in de regel opgenomen eis mag stellen of een nadere eis mag stellen." (MvT, p39)

Binnen de afwegingsruimte is het voor overheden dus ook mogelijk om aanvullende eisen te stellen.

\section{Rechtszekerheid in het geding?}

De Raad voor de Leefomgeving en Infrastructuur maakt in haar advies over de Omgevingswet de opmerking dat de flexibiliteit op zich niet nieuw is ten opzichte van bestaande wetgeving, maar stelt zich tegelijkertijd de vraag of de rechtszekerheid niet in het geding komt door deze ruimte. Flexibiliteit moet nadrukkelijk niet het 'recht van de sterkste' betekenen in de praktijk, aldus de RLI. Volgens hen moet de burger zekerheid over het proces worden geboden, door rechtszekerheid te borgen in de procedures, door de eis dat het afwegingsproces transparant moet zijn en dat bestuurders aan hun gemeenteraad, dan wel Provinciale Staten en in openbare documenten verantwoording afleggen over de beleidskeuzes die ten grondslag liggen aan het maatwerk en over de wijze waarop besluiten tot stand zijn gekomen (RLI, 2015).

\subsection{Informatiehuizen}

In de wetstekst over de Omgevingswet wordt niet concreet beschreven hoe informatie over de leefomgeving beschikbaar gesteld moet worden. In de memorie van toelichting op de wet wordt vermeld dat de informatievoorziening zal lopen via een digitaal stelsel van informatie dat 'de Laan van de Leefomgeving' wordt genoemd. Dat is nodig volgens de regering omdat op dit moment niet alle domeinen in de fysieke leefomgeving beschikken over gegevens met een vastgestelde bruikbaarheid of bestendigheid. Volgens de memorie van toelichting is het omzetten van het groeiende data-aanbod in voor besluitvorming relevante gegevens over de fysieke leefomgeving een kernopgave van de inzet van digitalisering (MvT, 52).

\section{I\&M vindt dat digitale ondersteuning beter moet}

Volgens een eigen analyse van het ministerie voor Infrastructuur en Milieu (I\&M) bestaat er een 'breed gedragen hypothese' dat er inderdaad veel te verbeteren valt met een betere digitale ondersteuning'. I\&M stelt dat veel handige websites, programma's en databanken op het gebied van de fysieke leefomgeving bestaan, maar de gebruiker, de initiatiefnemer, de belanghebbende of het bevoegd gezag zich in de praktijk een weg moet banen door een woud aan soms slecht vindbare en slecht op elkaar afgestemde ICT-voorzieningen. Ook stelt I\&M dat deze gegeven vaak niet geschikt om te gebruiken voor besluitvorming. (I\&M, 2014).

\section{Landschap ontbreekt in Laan van de Leefomgeving}

Tien informatiehuizen moeten samen 'de Laan van de Leefomgeving' vormen. Een digitaal één samenhangend, vraaggestuurd stelsel met één overkoepelende visie, aldus het ministerie van I\&M (I\&M, 2014). Het gaat op dit moment om de volgende informatiehuizen:

- Lucht;

- Water;

- Bodem \& Ondergrond;

- Natuur;

- Externe Veiligheid;

- Geluid;

- Cultureel Erfgoed;

- Ruimte;

- Bouw en Afval.

De wet voorziet niet in een informatiehuis over landschap. Natuur en cultuurhistorie maken wel onderdeel uit van de informatiehuizen. 


\section{Data of informatie is nog geen kennis}

In de stukken van de informatiehuizen en discussies hierover worden de termen data en informatie door elkaar gebruikt. Data verwijst naar ruwe gegevens. Pas als deze gegevens in een context worden geplaatst, ontstaat informatie. Als aan informatie ervaring wordt toegevoegd ontstaat kennis. Als voorbeeld; in een bijeenkomst werd genoemd dat uit telgegevens kan blijken dat er honderd buizerds op één perceel zitten. Als de gebruiker van die gegevens niet weet dat dit gaat om trektellingen, van overvliegende vogels, kan dat tot vreemde conclusies en gevolgen leiden. De hamvraag is daarom of je ruwe data aan burgers beschikbaar wilt stellen of geïnterpreteerde data.

\section{Businessmodel informatiehuizen nog niet uitgewerkt}

In verschillende documenten en tijdens bijeenkomsten over de informatiehuizen komt telkens het aspect de onduidelijkheid over een businessmodel onder de informatiehuizen te sprake. In een analyse van het informatiehuis natuur schrijft het Interprovinciaal Overleg (IPO) dat er een structureel financieringsmodel opgezet moet worden, waarin alle kosten op de lange termijn gedekt zijn. Ze noemt daarbij als voorbeelden de kosten voor de ondersteuning van de vrijwilligers en de discussie over het 'eigenaarschap' van de gegevens (Bekker \& Nikkels, 2015). Met andere woorden: krijgen Particuliere Gegevensbeherende Organisaties (PGO's) betaald op het moment dat ze gegevens aanleveren aan de informatiehuizen. In een discussie hierover met het programmateam 'Eenvoudig Beter' werd door het ministerie van I\&M benadrukt de gegevens in het informatiehuis open data moeten zijn. Een antwoord op de vraag wat dan het businessmodel moet zijn werd op dat moment niet gegeven (Natuur- \& Cultuurcafé 'Ruimtelijke ordening 2.0', Amersfoort, 6 oktober 2016).

\section{Overheid als Huismeester voor de informatiehuizen}

Het ministerie van I\&M stelt voor BIJ12 de rol van huismeester te geven voor het informatiehuis natuur (I\&M, 2014). Dat de provincies deze rol lijken te aanvaarden blijkt uit een stuk van het IPO waarin ze zichzelf ook die rol toedichten (Bekker \& Nikkels, 2015). Volgens I\&M heeft de huismeester van een informatiehuis de volgende taken (I\&M, 2014):

- eerste aanspreekpunt in het huis;

- ee huismeester is verantwoordelijk voor de veranderopgave om te komen tot een volwaardig informatiehuis;

- maakt namens het informatiehuis bindende operationele afspraken over het invullen van de aansluitvoorwaarden, standaarden, planningen en prestatiecriteria;

- gaat een alliantie aan met andere organisaties om kennis en capaciteit beschikbaar te krijgen, om te voldoen aan de behoeften van de gebruikers van de Laan;

- kan samenwerkingspartners zoeken om andere opdrachtenstromen aan te boren om daarmee de financiële basis van het huis verder te versterken.

Voor Cultuurhistorie wordt voorgesteld de bestaande Rijksdienst voor het Cultureel Erfgoed (RCE) als huismeester aan te stellen (I\&M, 2015 \& RCE, 2015). Volgens het ministerie van Onderwijs, Cultuur en Wetenschap (OCW) is de RCE is nu ook al de partij die veel data beheert over cultureel erfgoed. Daar komt dan wel de nieuwe taak bij in de vorm van het faciliteren en coördineren van andere bronhouders zoals Rijk, provincies, gemeenten en waterschappen. OCW constateert dat deze nieuwe taken een forse inspanning zullen vragen (OCW, 2015). 



\section{$3 \quad$ Natuur in de Omgevingswet}

\subsection{Plaats van natuur in de wet}

De Omgevingswet stelt in artikel 1.2 dat natuur een (essentieel) onderdeel is van de fysieke leefomgeving. In artikel 2.26 wordt gesteld dat het Rijk verplicht is regels op te stellen om programma's vast te stellen onder andere om Europese richtlijnen en nationale eisen uit te voeren. Deze regels moeten de achteruitgang van de staat of kwaliteit van de fysieke leefomgeving voorkomen of beperken. Voor natuur zijn de Europese Vogelrichtlijn en Habitatrichtlijn van belang.

Voor het bereiken en in stand houden van een veilige en gezonde fysieke leefomgeving en een goede omgevingskwaliteit (de eerste doelstelling van de Omgevingswet) zijn onderwerpen als nationaal belang aangemerkt, waaronder het "nationaal netwerk van natuur voor het overleven en ontwikkelen van flora- en faunasoorten waaronder biodiversiteit" ${ }^{6}$ (NNN). De uitvoering van het natuurbeleid is evenwel gedecentraliseerd conform het Natuurpact. Deze decentralisatie heeft zijn beslag gekregen in de Wet natuurbescherming.

De Wet natuurbescherming is op 1 januari 2017 in werking getreden en zal opgaan in de Omgevingswet. De meeste inhoudelijke regels komen niet terug in de Omgevingswet zelf, maar zijn opgenomen in de algemene maatregelen van bestuur van de Omgevingswet, met name het Besluit kwaliteit leefomgeving. De Aanvullingswet natuur zal in 2019 door de beide kamers van de Staten Generaal worden behandeld. In de AMvB's (in het Bkl) wordt wel het NNN gereguleerd maar niet de Natura 2000-gebiedsbescherming, de soortenbescherming en bosbescherming. Deze laatsten zullen beleidsneutraal in de Aanvullingswet natuur worden geregeld.

\subsection{Betekenis omgevingswet voor natur}

\section{Wettelijke bescherming soorten en gebieden}

Op 1 januari 2017 is de Wet natuurbescherming in werking getreden, waarin de wettelijke bescherming van Natura 2000-gebieden geregeld is, evenals de bescherming van soorten onder de Vogelrichtlijn, Habitatrichtlijn, en de verdragen van Bern en Bonn en de overige nationale soorten, en de bescherming van houtopstanden. Bij de parlementaire behandeling van het voorstel voor de Wet natuurbescherming is door het kabinet meermalen bevestigd dat het normenkader en de instrumenten ongewijzigd zullen overgaan en dat geen afbreuk wordt gedaan aan het beschermingsniveau ${ }^{7}$. Ook bij de presentatie van het concept Aanvullingswet natuur is door het ministerie van EZ gesteld dat het normenkader en de instrumenten van de Wet natuurbescherming ongewijzigd zullen overgaan in de Omgevingswet en onderliggende AMvB's, zonder dat afbreuk wordt gedaan aan het beschermingsniveau (mail ministerie van EZ d.d. 22 juni 2016).

Kajaan (2016) merkt echter op dat de consequenties voor de praktijk van natuurbescherming niet goed overzien kunnen worden. De artikelen vanuit de Wet natuurbescherming zullen deels worden opgenomen in de Omgevingswet en deels in onderliggende Besluiten. Omdat de parlementaire behandeling van de Aanvullingswet natuur (waar de Natura 2000-gebiedsbescherming, de soortenbescherming en bosbescherming in terecht gaan komen), en de bijbehorende uitvoeringsbesluiten, nog moet plaatsvinden, is het lastig de natuur- en landschapsbescherming nu al in zijn geheel in beeld te krijgen.

\footnotetext{
6 Tabel 2.2. Besluit kwaliteit leefomgeving

7 Mvt Aanvullingswet natuur
} 


\section{Provinciale verantwoordelijkheid}

In de Wet natuurbescherming is de verantwoordelijkheid voor het uitvoeren van natuurbeleid geheel gedecentraliseerd aan de provincies. Provincies zijn verantwoordelijk voor zowel de passieve als actieve gebiedenbescherming en soortenbescherming en voor het beheer van houtopstanden. De decentralisatie biedt provincies ruimte om bij het toetsen van plannen en projecten in en nabij Natura 2000-gebieden en het verlenen van ontheffingen bij soortenbescherming, rekening te houden met regionale belangen en regionale verschillen in duurzaamheid van soorten.

Via artikel 1.12 Wet natuurbescherming zijn provincies verplicht om ook actieve maatregelen te treffen ter bescherming van soorten. Daarnaast hebben provincies de vrijheid om zelfstandig gebieden aan te wijzen als 'bijzondere provinciale natuurgebieden' of 'bijzondere provinciale landschappen'. De ambitie hiervoor kan worden vastgelegd in natuurvisies. Om deze provinciale ambities uit te voeren, kunnen provincies gebruik maken van de omgevingsverordening. Daarin kunnen zij aangeven welke omgevingswaarden beschermd dienen te worden en tevens instructieregels opstellen voor doorwerking naar de gemeentelijke omgevingsverordening.

\section{Natuurvisie gaat op in omgevingsvisie}

De natuurvisie uit de Wet natuurbescherming heeft betrekking op de volle breedte van het beleidsveld voor natuur- en landschapsbescherming. In artikel 1.7 van de wet Natuurbescherming wordt voorzien in een provinciale natuurvisie, om samenhang van het natuur- en landschapsbeleid op provinciaal niveau te borgen, alsook de doorwerking van de kaders en ambities die zijn gesteld op nationaal niveau te verzekeren. Daarbij wordt expliciet aangegeven dat het te voeren provinciale beleid gericht moet zijn op onder andere het behoud en het zo mogelijk versterken van de biologische diversiteit en op het behoud, beheer en zo nodig herstel van natuur en waardevolle landschappen, met inachtneming van hun cultuurhistorische kenmerken, en op het versterken van de recreatieve, educatieve en belevingswaarde van natuur en landschap (artikel 1.7 Wet natuurbescherming).

De natuurvisie zal opgaan in de omgevingsvisie. De Omgevingswet stelt geen eisen meer aan de inhoud van de provinciale omgevingsvisie. De MvT Aanvullingsbesluit natuur onderbouwt het loslaten van deze eisen aan de inhoud door te stellen dat de fysieke leefomgeving vele aspecten omvat, waardoor gekozen is voor een globale beschrijving van de inhoud van de omgevingsvisie. Natuur en landschap maken integraal deel uit van deze fysieke leefomgeving en deze belangen moeten volwaardig worden meegewogen (MvT Aanvullingswetsvoorstel natuur pag. 13).

Tevens stelt de Omgevingswet geen eisen meer aan de actualisatie van de Rijksnatuurvisie, in tegenstelling tot de Wet natuurbescherming. Dit in het licht van flexibiliteit en het voorkomen van onnodige bestuurlijke lasten. Het is aan het bevoegd gezag om vast te stellen wanneer actualisatie gewenst is (MvT aanvullingswetvoorstel natuur).

\section{Natura 2000-beheerplan integraal?}

De eisen voor het vaststellen van een beheerplan voor Natura 2000-gebieden blijven onverkort gelden, evenals de verplichting voor het vaststellend bestuursorgaan om tijdig uitvoering te geven aan in een beheerplan opgenomen maatregelen. Door het beheerplan Natura 2000 in de Omgevingswet te verankeren wil het Rijk een integrale gebiedsaanpak verzekeren. In het Besluit kwaliteit leefomgeving is in artikel 4.29 en 4.30 aangegeven wat in het beheerplan Natura 2000 moet worden beschreven en wanneer een beheerplan moet worden vastgesteld. De vraag is of het beheerplan voor Natura 2000gebieden zich hiervoor leent.

\section{Alle natuuractiviteiten verlopen via een omgevingsvergunning}

De vergunning beschermde gebieden en de ontheffing beschermde soorten zullen gaan verlopen via een omgevingsvergunning. Bij een separate natuurtoets zal dus ook de provincie (of in gevallen van nationaal belang het rijk) een omgevingsvergunning kunnen verlenen. In de Omgevingswet wordt hierbij gesproken van Natura 2000-activiteiten of flora- en fauna-activiteiten.

Als sprake is van een meervoudige aanvraag voor een omgevingsvergunning (dus bijvoorbeeld bouwen en een Natura 2000-activiteit) zal de gemeenten de omgevingsvergunning verlenen waarbij de inhoudelijke natuurtoets door de provincie wordt uitgevoerd. In plaats van de huidige Verklaring 
van geen bedenkingen verloopt het aanhaken van de natuurtoestemming onder de Omgevingswet via een Advies met instemming.

\section{Beoordelingsregels voor afwegen activiteit?}

Om te beoordelen of een aangevraagde omgevingsvergunning met een Natura 2000-activiteit of een flora- en fauna-activiteit verleend kan worden, zullen beoordelingsregels worden opgesteld. Het gaat hierbij om de toetsingsgronden, of normen, die volgen uit artikel 9 Vogelrichtlijn en art 16 Habitatrichtlijn (de bepalingen wanneer een derogatie kan worden verleend). Deze beoordelingsregels zullen worden opgenomen in het Besluit kwaliteit leefomgeving. Onder andere de volgende zaken zullen worden geregeld via het $\mathrm{Bkl}^{8}$ :

- Uitzondering van het verbod op het storen van vogels als er geen wezenlijke invloed op de staat van instandhouding is.

- Uitzondering op de soortenbeschermingsverboden ingeval de flora- en fauna-toets in het kader van een ander besluit wordt uitgevoerd.

- Uitzondering op de soortenbeschermingsverboden ingeval de handeling een instandhoudingsmaatregel of een passende maatregel voor een Natura 2000-gebied is.

- Uitzondering op de soortenbeschermingsverboden ingeval de handelingen plaatsvindt overeenkomstig een Natura 2000-beheerplan of een programma (programmatische aanpak)

- Algemene voorwaarden om vergunning te verlenen.

- Uitzondering vergunningplicht ingeval de Natura 2000-toets in het kader van een ander besluit wordt uitgevoerd.

Bovenstaande punten zijn nu verwoord in artikelen van de Wet natuurbescherming en betreffen vormen van vrijstellingen. De vraag is of het definitieve Bkl meer handvatten, dus beoordelingsregels, gaat geven voor afweging.

\section{Compensatie in het NNN beter geborgd}

Het NNN gaat beschermd worden via de instructieregels in het Besluit kwaliteit leefomgeving, afdeling 7.3. Onder de omgevingswet worden de NNN-gebieden aangewezen en begrensd via de omgevingsverordeningen van de provincies (Zwier, 2016). Net als in het huidige Barro moeten provincies het NNN aanwijzen en begrenzen, de wezenlijke kenmerken en waarden vaststellen en het beschermingsregime implementeren. Nieuw ten opzichte van het Barro is dat als sprake is van compensatie in de vorm van het toevoegen van een nieuw gebied aan het NNN, dit gebied "tijdig" (dixit art. 7.8 lid 2 Bkl) moet worden begrensd en aangewezen in de omgevingsverordening. Dit volgt uit aanbevelingen van de Algemene Rekenkamer om de compensatie beter te borgen (Zwier, 2016).

\section{Samenvattend}

In de Omgevingswet is de bescherming van Natura 2000-gebieden en soorten wettelijk geregeld. In het Ontwerpbesluit kwaliteit leefomgeving is de bescherming van het NNN geregeld via instructieregels aan de provincies. In dit ontwerpbesluit staat ook al omschreven wat in een beheerplan Natura 2000 moet worden beschreven en wanneer een beheerplan moet worden vastgesteld.

Zaken voor natuur die nog geregeld moeten worden in het Ontwerpbesluit (nu gereserveerd) via het Aanvullingsbesluit natuur zijn:

- het beheer van natuurgebieden;

- provinciale beoordelingsregels voor een afwijkactiviteit (Natura 2000-activiteit en/of flora- en fauna activiteit);

- omgevingsvergunning afwijkactiviteit;

- omgevingsvergunning natuuractiviteit;

- monitoring en informatie natuur.

\footnotetext{
${ }^{8}$ In het Ontwerpbesluit kwaliteit leefomgeving zijn deze zaken nog niet ingevuld. Het onderdeel Afdeling 7.5 (Instructieregels over de provinciale beoordelingsregels voor een afwijkactiviteit) is gereserveerd. Ook de onderdelen Afdeling 8.1 (Omgevingsvergunning afwijkactivteit); 8.6 (Omgevingsvergunning natuuractiviteit) en 10.4 (Monitoring en informatie natuur) zijn gereserveerd.
} 


\subsection{Natuur- en omgevingswaarden}

De Omgevingswet verplicht Rijk noch provincies om omgevingswaarden voor natuur vast te stellen. Wettelijk is wel bescherming VHR-waarden en nationale soorten geregeld, maar de ambitie hoe dit te verwezenlijken komt in de natuurvisie; het vastleggen van omgevingswaarden zal plaatsvinden in de omgevingsverordening, waarin ook regels ter uitvoering zullen worden opgesteld, al dan niet in de vorm van instructieregels.

In het Besluit kwaliteit leefomgeving staat dat provincies in hun omgevingsverordening de wezenlijke kenmerken en waarden van het NNN moeten opnemen. Daarbij gaat het om aanwezige natuurwaarden. Voor gebieden met een functie natuur worden ook potentiële natuurwaarden en de daarvoor vereiste bodem- en watercondities als wezenlijke kenmerken en waarden aangemerkt, voor zover deze natuurwaarden en condities in het licht van de internationale biodiversiteitdoelstellingen relevant zijn (artikel 7.6 lid 3).

Men kan dus stellen dat omgevingswaarden voor natuur worden vastgelegd in omgevingsverordeningen in de vorm van wezenlijke waarden en kenmerken voor het NNN.

\subsection{Beleidsneutrale omzetting}

\section{Aanvullingswet natuur binnen de Omgevingswet}

Het Aanvullingswetsvoorstel natuur Omgevingswet (ofwel Aanvullingswet natuur) is op 3 juli 2018 aan de Tweede Kamer aangeboden. De Aanvullingswet natuur "voorziet in wijzigingen van de Omgevingswet, zodat die wet straks over de nodige bevoegdheden en instrumenten beschikt om regels te stellen en maatregelen te treffen voor de bescherming van de natuur" (VNG, 2018 ${ }^{9}$ ). Dit wetsontwerp ligt thans bij het parlement en kan dus nog omstandig geamendeerd worden door de Tweede Kamer.

\section{Omzetting natuurwetgeving in Omgevingswet niet altijd beleidsneutraal}

De Memorie van Toelichting Aanvullingswet natuur vermeldt dat de Wet natuurbescherming en alle daarin opgenomen normen en instrumenten ongewijzigd (beleidsneutraal) zullen worden gecontinueerd in de Omgevingswet en bijbehorende AMvB's en dat geen afbreuk wordt gedaan aan het beschermingsniveau. Hiervoor is het aanvullingsbesluit natuur kaderstellend, omdat hierin de inhoudelijke normen terecht zullen komen, maar op het moment van schrijven van deze rapportage waren de teksten voor dit besluit nog niet gepubliceerd. Hierdoor kan nog geen conclusie getrokken worden of er inderdaad sprake is van een beleidsneutrale omzetting.

Op basis van de tekst in de aanvullingswet natuur stelt de Stichting Natuur en Milieu (2017) al wel dat sommige onderwerpen uit Wet natuurbescherming niet direct terugkomen in de Omgevingswet, omdat ze worden verondersteld materieel te worden gedekt door andere bepalingen uit de Omgevingswet:

- Natuurvisies zijn straks niet meer verplicht. Natuurvisies gaan op in omgevingsvisies. De Omgevingswet verplicht niet tot een regelmatige herziening van een omgevingsvisie. De Omgevingswet bepaalt ook niet dat in een omgevingsvisie natuurbeleid aan bod moet komen (zie ook 3.2). De inhoudelijke eisen voor de natuurvisie uit de Wet natuurbescherming ontbreken voor de omgevingsvisie onder de Omgevingswet. Hierdoor ontstaat theoretisch het risico dat natuurbeleid minder aandacht zal krijgen binnen (provinciaal) beleid. Theoretisch, omdat provincie natuur als één van hun kerntaken zien.

- Het laten vervallen van de verplichting om een natuurvisie op te stellen is niet beleidsneutraal. De vraag is wel: wat gaan provincies straks doen? Hoe nemen zij natuurbescherming mee in integraal beleid?

- Algemene zorgplicht: De zorgplicht is nu geregeld in Wet natuurbescherming en gericht op instandhoudingsdoelen, dit is straks geregeld in Besluit activiteiten leefomgeving (Bal) en gericht op voorkomen van verslechtering en verstoring. Ook dit is geen beleidsneutrale omzetting.

\footnotetext{
${ }^{9}$ https://vng.nl/onderwerpenindex/ruimte-en-wonen/omgevingswet/juridische-routekaart/aanvullingswet-natuur
} 
Backes en Freriks (2017) signaleren veranderingen voor doelstellingen en het regelen van vrijstellingen.

- Doelstellingen: De expliciete doelstelling van de natuurwetgeving verdwijnt en gaat op in een ruime, maar vage doelstelling van bescherming en verbetering van het leefmilieu. In de Omgevingswet is geformuleerd dat het streven naar een goede omgevingskwaliteit ook nodig is 'vanwege de intrinsieke waarde van de natuur', maar intrinsieke waarde van natuur heeft geen zelfstandig normatief karakter en creëert geen eigenstandige bevoegdheden. Onder de Omgevingswet is er geen enkel instrument, plan, zorgplicht, algemene regel, vergunningstelsel of financieel kader meer dat exclusief bedoeld is om de doelstellingen van behoud en ontwikkeling van de natuur te dienen (Backes en Freriks, 2017).

- Backes en Freriks (2017) geven verder aan dat de nadere invulling van het meldingenstelsel voor vrijstellingen voor nationale (overige) soorten onder de Omgevingswet niet langer een bevoegdheid is van Provinciale Staten (PS). Onder de Wet natuurbescherming is vrijstelling via melding geregeld in een ministeriële regeling en PS kan in een verordening aangeven voor welke soorten en de regels waaraan melding moet voldoen. Onder de Omgevingswet wordt vrijstelling via melding geregeld in een AMvB: de algemene regels voor welke activiteiten een vrijstelling geldt komen in het Besluit activiteiten leefomgeving en de regeling van de vergunning wordt uitgewerkt in het Bkl.

Dit betekent dat het huidige niveau van bescherming toch verandert en dat de omzetting mogelijk een afzwakking van de bescherming en intenties van de huidige Wet natuurbescherming betekent. Hoewel I\&M aangeeft een gelijkwaardig beschermingsniveau na te streven, is de vraag of dit gegarandeerd kan worden nu verschillende bestuursorganen ruimte krijgen om zelf normen te stellen. De waarborg van de kwaliteit van de leefomgeving ligt nu bij decentrale overheden en de vraag is welke omgevingswaarden zij zullen vaststellen. Van rijkswege zijn alleen omgevingswaarden vastgesteld voor luchtkwaliteit, waterkwaliteit en veiligheid waterkeringen (in het Bkl). Voor de omgevingswaarde natuur is bescherming van de Wet natuurbescherming/VHR de ondergrens.

\section{Integrale visie omgevingsrecht onvoldoende uitgewerkt in Omgevingswet}

De uitwerking van de Omgevingswet, als kaderwet met vele onderliggende instrumenten, staat haaks op de integraliteit die met de Omgevingswet beoogd is.

- De onlosmakelijke samenhang voor activiteiten is losgelaten, waardoor voor complexe of samenhangende activiteiten een initiatiefnemer toch weer kan kiezen voor een enkelvoudige omgevingsvergunning. Voor een enkelvoudige omgevingsvergunning die alleen een Natura 2000activiteit of flora- en fauna-activiteit betreft, is wel Gedeputeerde Staten (GS) straks het bevoegd gezag. Echter, het loslaten is niet in lijn met de integrale benadering die de Omgevingswet beoogt.

- Onduidelijk is hoe een integrale beoordeling moet plaatsvinden en op welke wijze bestuursorganen verschillende belangen moeten afwegen. Ieder bestuursorgaan kan zijn eigen 'mengpaneel' samenstellen, met risico dat 'zachte' waarden als natuur minder duidelijk zichtbaar zijn dan economische waarden.

- Doelen en maatregelen uit de omgevingsvisie en het programma, en daarmee samenhangende omgevingswaarden, zijn zelfbindend, tenzij is voorzien in doorwerking naar andere bestuursorganen via instructieregels.

\section{Duurzame gebiedsontwikkeling onder de Omgevingswet}

Nieuw is dat de Omgevingswet in de considerans expliciet duurzame ontwikkeling als oogmerk van de wet noemt. In de begrippenlijst achterin de wet wordt deze duurzame ontwikkeling gedefinieerd als: ontwikkeling die voorziet in de behoeften van de huidige generatie zonder de mogelijkheden voor toekomstige generaties om in hun eigen behoeften te voorzien in gevaar te brengen. Dit is evenwel een definitie die zich lijkt te beperken tot intergenerationele solidariteit. Het volgt nog de traditionele definitie uit het befaamde Brundtland Report uit 1987: duurzame ontwikkeling is ontwikkeling die 'meets the needs of the present without compromising the ability of future generations to meet their own needs'.

Duurzame ontwikkeling kan intussen ook wel breder, duidelijker en minder als politieke platitude geformuleerd worden. Het kan zelfs als dwingend rechtsbeginsel in de milieu- of omgevingswet gepostuleerd worden, zoals Nieuw-Zeeland al gedaan heeft in de New Zealand Resource Management 
Act 1991 (RMA) (Grinlinton, 2016). Daar is Nederland nog ver van verwijderd want de Omgevingswet noemt een duurzaamheidsbeginsel niet eens in de wettekst. In art. 23.6 wordt wel iets gezegd over doorwerking van beginselen, maar dit betreft dan (a) slechts enkele andere milieubeginselen (zoals het voorzorgsbeginsel en het beginsel van preventief handelen) en (b) beginselen waar alleen de $A M v B$ 's rekening mee moeten houden middels een motivering in de nota van toelichting bij die AMvB's.

In Nederland is een beginsel van duurzame (gebieds)ontwikkeling hooguit een beleidsbeginsel en nog steeds geen rechtsbeginsel, laat staan een leidend rechtsbeginsel aan de top van het systeem van omgevingsrechtelijke wetgeving zoals in Nieuw-Zeeland. In de Omgevingswet zelf lezen we niets over dit beginsel. Dit betekent dat we niet verwachten dat deze beginselen serieus doorwerken in de beoordelingskaders voor het omgevingsplan, de omgevingsverordening, omgevingsvergunningen of projectbesluiten. De considerans noemt het begrip duurzaamheid wel, maar beperkt zich blijkens de definitie in de wetsbijlage tot de aloude Brundtland-definitie; deze zegt dus weer niets over een triple P-weging of een balans van ecosysteemdiensten.

De komende Omgevingswet bezit geen imperatief of 'incentive' om het concept van ecosysteemdiensten een rol te laten spelen. Evenals Europese milieurichtlijnen (zoals de Kaderrichtlijn Water en de Habitatrichtlijn) bevat ook deze nieuwe nationale wetgeving rechtsdogmatisch eerder blokkades voor een duurzaamheidsweging met behulp van het ecosysteemdiensten-concept (Graaf et al, 2017 en Kistenkas \& Bouwma, 2017). Zowel de Natura 2000-habitattoets als de watertoets uit de Kaderrichtlijn Water zijn immers 'nee, tenzij'-toetsen waarbij alleen sommige en dus beperkte ecologische desiderata een rol mogen spelen. Daarmee worden hele clusters van (andere) ecosysteemdiensten rechtens uitgesloten van meeweging. 


\section{$4 \quad$ Landschap en cultuurhistorie in de Omgevingswet}

\subsection{Plaats van landschap in de Omgevingswet}

\section{Landschap in de kern van de wet}

De Omgevingswet noemt landschap expliciet als onderdeel van de fysieke leefomgeving. In de memorie van toelichting staat de Omgevingswet mede gericht is op:

"het bereiken en in stand houden van een goede landschapskwaliteit en op een doelmatig beheer, gebruik en ontwikkeling van landschap" (Tweede Kamer, 2014).

In artikel Artikel 1.6 van de wet staat: (zorgplicht voor een ieder)

"Een ieder draagt voldoende zorg voor de fysieke leefomgeving."

Omdat landschappen en cultureel erfgoed onderdeel uitmaken van het begrip fysieke leefomgeving in de wet, kun je stellen dat landschap in principe in de kern van de wet is verankerd. Wat dit in de praktijk betekent zal moeten blijken en is nog moeilijk te voorspellen.

\section{Link met de Wet natuurbescherming}

Het Rijk is verplicht om landschap een plaats te geven in een nationale natuurvisie, vanuit de nieuwe Wet natuurbescherming. Een verplichting die hoogstwaarschijnlijk over zal gaan naar de Omgevingswet, waarin de wetstekst van de nieuwe Wet natuurbescherming in 2017 geïntegreerd zal worden. Letterlijk staat er in de Wet natuurbescherming:

"de bescherming van waardevolle landschappen, in nationaal en internationaal verband, en het behoud en het zo mogelijk versterken van de recreatieve, de educatieve en de belevingswaarde van natuur en landschap, in samenhang met het beleid om te komen tot een verduurzaming van de economie" (Staatsblad 34, 2016, artikel 1.5 lid 2)".

In de memorie van toelichting staat ook verwoord dat de regels voor cultureel erfgoed in de wet en uitvoeringsregels zijn vormgegeven door drie verdragen die gesloten onder de auspiciën van de Raad van Europa:

1. Verdrag van Granada.

2. Verdrag van Malta.

3. Europese Landschapsconventie (ELC).

\section{Mogelijke uitwerking van de ELC in de Omgevingswet}

In de Nota Ruimte uit 2005 werden nog twintig over het hele land verspreide Nationale Landschappen aangewezen die beschermd zouden moeten worden door een 'ja, mits'-regime. Dit was toen nog rijksbeleid. In de daaropvolgende Structuurvisie Infrastructuur en Ruimte (SVIR) uit 2012 werd dit niet langer meer als een rijksverantwoordelijkheid gezien en aan de provincies gedelegeerd (Kistenkas et al., 2017). In de Provinciaal Ruimtelijke Verordeningen zouden provincies hun eigen landschapsrecht kunnen codificeren. Interessant is het nu om te bedenken hoe dit provinciale landschapsrecht er onder de nieuwe Omgevingswet uit zal (kunnen) komen te zien.

Landschap wordt weliswaar in art. 1.2 Ow als onderdeel van de fysieke leefomgeving genoemd, maar vervolgens wordt er in die wet en ook in de onderliggende AMvBs zoals het Besluit kwaliteit leefomgeving $(\mathrm{Bkl})$ niets verder uitgewerkt. In een kopje (de aanhef van paragraaf 5.1.5) van het $\mathrm{Bkl}$ wordt nog wel 'beschermen van landschappelijke waarden' genoemd, maar in de wettekst zelf komt dit niet meer terug. Dat betekent dat de centrale overheid geen normatief kader geeft voor landschapsbescherming. Of anders gezegd; er wordt door het Rijk geen afdwingbaar rechtsregime aangereikt. De vraag is of deze inertie van de Rijksoverheid niet strijdig is met het al sinds 2005 van kracht zijnde Europees Landschapsverdrag, ook wel Europese Landschapsconventie (ELC) of Verdrag van Florence genoemd. Dit verdrag verwijst in art. 4 naar het subsidiariteitsbeginsel (dat uitgaat van zowel decentrale autonomie als ook centrale hiërarchiek) en eist in hoofdstuk II expliciet nationale 
maatregelen (national measures), dus van de centrale overheid. In art. 6 staat letterlijk: 'Elke Partij (bedoeld wordt weer: nationale overheid) verbindt zich ertoe kwaliteitsdoelstellingen voor landschappen te omschrijven'.

In de officiële Engelse tekst heten deze kwaliteitsdoelstellingen 'landscape quality objectives', hetgeen sterk doet denken aan de 'nature conservation objectives' uit de strenge habitattoets voor de Europese Natura 2000-gebieden. De habitattoets geeft, zoals bekend, deze natuurgebieden een zeer sterke juridische bescherming en rechterlijke afdwingbaarheid. Met deze verdragstekst van de ELC in de hand zou men dus naar analogie van de habitattoets zeer verdedigbaar ook voor een landschapstoets kunnen pleiten. Verschil is dat de Habitatrichtlijn van de EU afkomstig is (en streng uitgelegd wordt door de eigen EU-rechter) en de ELC van de Raad van Europa (RvE) wat kennelijk als minder urgent en dwingend wordt beschouwd (RvE kent immers geen ingebrekestellingsprocedures zoals de EU die wel kent).

Zolang er nog geen nationaal landschapsrecht bestaat, zouden evenwel provincies al wat kunnen doen. In provinciale ruimtelijke verordeningen kan men al een 'ja, mits'-beschermingsregime opnemen, compleet met toetsing van gemeentelijke bestemmingsplannen aan landschappelijke kernkwaliteiten. Bekend is het voorbeeld uit de provinciale omgevingsverordening van Overijssel met kernkwaliteiten voor het Nationaal Landschap IJsseldelta en Nationaal Landschap Noordoost-Twente waaraan via een ja, mits-regime aan getoetst moet worden (art. 2.6.3 en 2.6.4 uit de provinciale verordening). Er geldt aldus een 'ja, mits'-bescherming zoals we die voor 2012 landelijk wilden regelen voor alle Nationale Landschappen in het huidige Besluit algemene regels ruimtelijke ordening (Barro). Bovendien heeft deze provincie, naast specifiek landschapsrecht voor deze twee gebieden, ook een Catalogus Gebiedskenmerken als generiek landschapsrecht uitgewerkt voor de hele provincie.

Ook de nieuwe Wet natuurbescherming (Wnb) schept intussen de mogelijkheid van zogeheten bijzondere provinciale landschappen (art. 1.12 lid $3 \mathrm{Wnb}$ ). Gedeputeerde Staten kunnen deze gebieden aanwijzen, maar zijn daartoe niet verplicht. Zo blijft het landschapsrecht zonder wettelijke aansturing vanuit de centrale overheid dus steken in vrijblijvendheid: een provincie kan wat doen, maar hoeft dat niet. Het enige voorbeeld tot nog toe is Midden-Delfland waarvoor de provincie ZuidHolland echter geen ja, mits-regime heeft doen gelden. Het ontbreekt eenvoudig aan een 'ja, mits'regime in het Barro (en straks in het $\mathrm{Bkl}$ ) dat provincies verplicht zouden moeten uitwerken middels begrenzing en kernkwaliteiten in hun Provinciaal Ruimtelijke Verordeningen (PRV's).

Provincies zouden echter veel meer afdwingbaar landschapsrecht kunnen ontwikkelen middels het instrumentarium van de komende Omgevingswet. Zo zouden zij kernwaarden van hun regionale landschappen kunnen vastleggen in hun instructieregels voor het gemeentelijk omgevingsplan: in de omgevingsverordening zouden zij weer een 'ja, mits'-regime kunnen opnemen met verplichte toetsing aan kernwaarden van hun provinciale landschapsgebieden. Flankerend kan ook de provinciale omgevingsvisie nog beleid hieromtrent vastleggen dat indirect toch weer juridisch kan doorwerken via de reactieve interventiebevoegdheid, de rechtsopvolger van de Reactieve Aanwijzing (RA). Deze reactieve interventiebevoegdheid kan immers aangewend worden wanneer gemeenten in strijd met vooraf bekend gemaakt provinciaal beleid handelen. Zo'n provinciale omgevingsvisie is het prototype van vooraf bekend gemaakt provinciaal beleid. Een omgevingsvisie is op zichzelf niet juridisch bindend, maar via de reactieve interventiebevoegdheid kan het wel weer rechtens relevant en juridisch dwingend zijn.

Eveneens flankerend voor het provinciale landschapsrecht zou nog de Ladder voor duurzame verstedelijking kunnen zijn. Provincies kunnen deze ladder immers nader inkaderen in hun verordening. Ook langs die weg kan men gemeenten aansturen op het gebied van landschappelijke bescherming.

Al deze vormen zijn vrijblijvend, provincies hoeven hier geen invulling aan te geven, zolang het niet door het Rijk wordt opgelegd, via een Algemene Maatregelen van Bestuur (AMvB), zoals het Besluit kwaliteit leefomgeving, van de nieuwe Omgevingswet. Daarin zou bijvoorbeeld aangeven kunnen worden dat er nationale of regionale landschappen door provincies aangewezen moeten worden, waarvoor een 'ja, mits'-regime zou kunnen gelden met toetsing aan door hen vast te stellen 
kernwaarden voor die gebieden, zoals in de Nota Ruimte werd gedaan voor de Nationale Landschappen. In deze constructie geeft de Rijksoverheid aan dat het moet gebeuren en bepaalt de provincie hoe dat moet gebeuren (zie figuur 4.1). Dit lijkt op subsidiariteit en decentralisatie in optima forma en sluit aan bij de verplichtingen uit het ELC van de Raad van Europa. Deze vorm is ook een typisch klassiek Nederlands model: autonomie en hiërarchie in één. Iedere overheidslaag doet een deel: het Rijk geeft het 'ja, mits'-regime aan, de provincies vullen dat nader in en de gemeente voert dat uit. Het vereist dus wel dat men de systematiek van de nieuwe Omgevingswet ten volle begrijpt en benut. Daarbij is de ' harde kern' dus de inzet van instructieregels, zowel van Rijk (AMvBs) als provincies (omgevingsverordening). Maar zelfs de provinciale omgevingsvisie kan indirect rechtens relevant worden via de reactieve interventiebevoegdheid. Eveneens flankerend kan mogelijk nog de (eventueel door de desbetreffende provincie aangevulde) Ladder voor duurzame verstedelijking (LDV) zijn (Kistenkas et al., 2017).

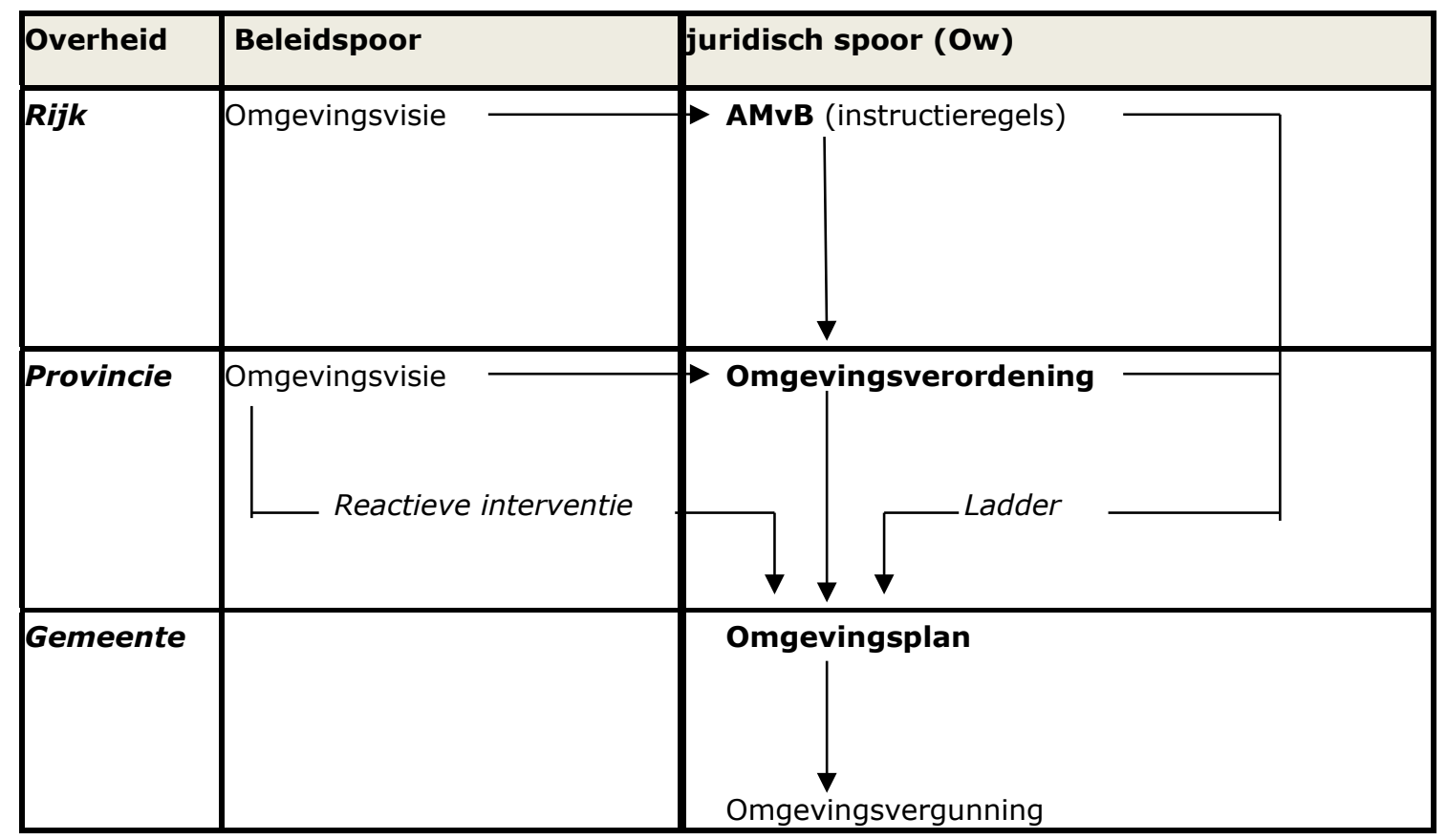

Figuur 4.1 Ook de Omgevingswet biedt mogelijkheden voor een getrapte uitwerking van landschapsbeleid (naar Kistenkas et al., 2017).

\subsection{Omgevingswaarden}

\section{Geen omgevingswaarden voor landschap}

De wet biedt provincies en gemeenten in principe de mogelijkheid om zelf omgevingswaarden te stellen en dat zou in theorie ook mogelijk zijn voor landschap en cultuurhistorie. Of dit in de praktijk ook zal gebeuren valt te bezien, omdat het begrip omgevingswaarde in de wet vooral wordt omschreven als middel om kwantitatieve normen te stellen voor zaken als milieukwaliteit, waaronder lucht- en waterkwaliteit.

\subsection{Instructieregels}

\section{Geen instructieregels voor landschap}

Hoewel het begrip "landschappen" nadrukkelijk wordt genoemd als onderdeel van het begrip 'leefomgeving' in de Omgevingswet maakt de memorie van toelichting duidelijk dat de uitwerking hiervan volledig wordt overgelaten aan decentrale overheden. Uitzondering daarop zijn de werelderfgoederen en beschermde stads- en dorpsgezichten. Omdat landschap hiermee geen rijksbelang is, bevat het Besluit kwaliteit leefomgeving dan ook geen instructieregels aan decentrale overheden hoe ze uitvoering moeten geven aan de twee belangrijkste principes van landschap als onderdeel van de leefomgeving te weten, het in onderlinge samenhang: 
- Bereiken en in stand houden van een veilige en gezonde fysieke leefomgeving en een goede omgevingskwaliteit;

- Doelmatig beheren, gebruiken en ontwikkelen van de fysieke leefomgeving ter vervulling van maatschappelijke behoeften.

(artikel 1.3).

\section{Wel instructieregels voor cultureel erfgoed}

In het Besluit kwaliteit leefomgeving staan wel instructieregels van het Rijk aan provincies om in hun provinciaal ruimtelijke verordening regels te stellen over cultureel erfgoed:

- 'Het behoud van cultureel erfgoed;

- Het behoud van de uitzonderlijke universele waarde van werelderfgoed, in ieder geval ter uitvoering van het werelderfgoedverdrag.'

(artikel 2.27)

Daarnaast bevat het BKL instructieregels richting gemeenten, als het gaat om zaken die ze verplicht zijn om uit te werken in hun omgevingsplan of projectbesluiten:

- 'Het behoud van cultureel erfgoed, met inbegrip van bekende of aantoonbaar te verwachten archeologische monumenten, in ieder geval ter uitvoering van het verdrag van Granada en het verdrag van Malta;

- Het behoud van de uitzonderlijke universele waarde van werelderfgoed, in ieder geval ter uitvoering van het werelderfgoedverdrag.'

(artikel 2.28)

\section{$4.4 \quad$ Unesco-werelderfgoed}

Paragraaf 5.1.5 van het Bkl heeft weliswaar als aanhef het 'beschermen van landschappelijke of stedenbouwkundige waarden en cultureel erfgoed' maar schuift behoud van cultureel erfgoed volledig door naar de gemeenten met hun omgevingsplan (art. $5.130 \mathrm{Bkl}$ ) en regelt verder alleen de bescherming van de vier Unesco-werelderfgoederen (art. 7.3/4 Bkl). De kernwaarden van Stelling van Amsterdam, Beemster, Nieuwe Hollandse Waterlinie en de Limes worden in een bijlage bij het Bkl opgesomd en moeten worden uitgewerkt door de desbetreffende provincies (art. 7.4 lid 2 Bkl). Van het ja, mits-regime uit het huidige Barro blijft alleen art. 7.4 lid 4 Bkl over: regels in het belang van instandhouding en versterking van de kernkwaliteiten 'houden in ieder geval in dat geen activiteiten worden toegelaten die de kernkwaliteiten aantasten'. In wezen zijn dit provinciale instructieregels voor de gemeenten en hun omgevingsplannen.

Hier verloopt regulering en bescherming dus via de trits Rijk (AMvB), provincie (Omgevingsverordening) en gemeente (Omgevingsplan).

\subsection{Overig landschapsrecht}

Buiten de Unesco-werelderfgoederen biedt het Bkl geen beschermingsregime voor landschappen. Alles wordt doorgeschoven naar het gemeentelijke omgevingsplan (art. 5.130 Bkl). Zo hoopt men dat aldus voldaan wordt aan de landschapsrechtelijke verplichtingen uit de Europese Landschapsconventie (ELC). De gemeenten zijn voor verdragsverplichtingen de verantwoordelijke overheidslaag aldus de Nota van Toelichting (NvT). De NvT merkt hier verder over op: "Met het inventariseren en beoordelen van cultuurlandschappen en het opnemen daarvan in de omgevingsvisie en het omgevingsplan, wordt ook uitvoering gegeven aan het Europees landschapsverdrag" (NvT-paragraaf 8.1.7.5 Cultureel erfgoed).

Het is zeer de vraag of dit rechtens klopt nu het ELC nadrukkelijk ook om national measures (dus ook van de Rijksoverheid) vraagt langs lijnen van subsidiariteit, dus via de aloude trits van Rijk-provinciesgemeenten (vgl. art. 4 en 6 ELC). De ELC eist in wezen een landschapstoets zoals wij die ook kennen uit het natuurbeschermingsrecht, dus een soort habitattoets voor landschappen waarbij getoetst moet 
worden aan landscape quality objectives. ${ }^{10}$ Men zou hier kunnen verdedigen dat het Bkl strijdig is met of althans tekort schiet ten opzichte van de ELC.

\title{
4.6 Illustratie Steenwijkerland: uitwerking van landschapsbeleid
}

\begin{abstract}
Verbreed bestemmingsplan buitengebied Steenwijkerland
Gemeente Steenwijkerland heeft gebruik gemaakt van de mogelijkheid om, vooruitlopend op de formele invoering van de Omgevingswet, een omgevingsplan te maken in plaats van een bestemmingsplan. Omdat de Omgevingswet nog niet in werking is getreden, heet dit plan 'een bestemmingsplan met verbrede reikwijdte'. Met een bestemmingsplan met verbrede reikwijdte kunnen gemeenten sinds 2014 vooruit lopen op de komst van het omgevingsplan uit de Omgevingswet, door zich aan te melden als experiment binnen de Crisis- en herstelwet (IenM, 2017). De gemeente Steenwijkerland heeft zo de gelegenheid gekregen tot 'een innovatief planologisch experiment' voor haar buitengebied ex art. 7c van het Besluit uitvoering Crisis- en herstelwet (Chw) binnen de $11^{\mathrm{e}}$ tranche van de Chw toestemming van de minister gekregen om dit plan te mogen maken (Bugel Hajema, 2017).
\end{abstract}

\section{Generiek en specifiek landschapsbeleid in Omgevingsplan}

De provincie Overijssel heeft een specifiek landschapsbeleid voor twee Nationale Landschappen (IJsseldelta in Salland en Noordoost-Twente in Twente). Voor deze specifieke gebieden geldt, op grond van de provinciale omgevingsverordening (art. 2.6.1-2.6.4 Provinciale Omgevingsverordening Overijssel), een ja, mits-beschermingsregime waarbij gemeentelijke bestemmingsplannen moeten bijdragen aan behoud of ontwikkeling van de kernkwaliteiten van deze gebieden. De provincie heeft hiermee het door de Rijksoverheid verlaten specifieke landschapsbeleid voortgezet en overgenomen (ja, mits-regime, toetsing aan kernkwaliteiten). Daarnaast heeft de provincie ook een generiek landschapsbeleid voor de (gehele) provincie gebaseerd op een Catalogus Gebiedskenmerken (bijvoorbeeld voor laagveenontginningen, kraggenlandschap etc).

De gemeente Steenwijkerland heeft geen Nationale Landschappen binnen de gemeentegrenzen, maar heeft wel het generieke landschapsbeleid van de provincie uitgewerkt en geïmplementeerd in het Omgevingsplan nieuwe stijl; dat wil zeggen, een Omgevingsplan dat al is opgesteld als 'bestemmingsplan met verbrede reikwijdte' zoals bedoeld in de Stelselherziening Omgevingswet.

\section{Beleidsregels als tussenschakel}

De (nog globale) provinciale gebiedskenmerken zijn daarbij door de gemeente nader aangescherpt in omgevingsvisie en omgevingsplan. Opvallend is dat de gemeente ook nog een eigen tussenschakel heeft ingevoegd van beleidsregels van B\&W (Beleidsnotitie Beeldkwaliteit Buitengebied) (zie figuur 4.2). Dit zijn geen rechtsregels oftewel algemeen verbindende voorschriften (a.v.v.'s) zoals in een verordening of ruimtelijk plan doch beleidsregels. De voordelen van beleidsregels boven rechtsregels zijn dat ze betrekkelijk snel en eenvoudig door een bestuursorgaan kunnen worden gewijzigd, maar vooral ook dat voor beleidsregels (anders dan voor rechtsregels) een zogenoemde inherente afwijkingsbevoegdheid geldt. Het bestuursorgaan is niet rechtens verplicht de beleidsregels toe te passen, iets wat ten principale wel voor rechtsregels geldt. Rechtsregels zijn immers altijd in directe zin recht, beleidsregels hebben slechts een indirecte status via de werking van de abbb's (algemene beginselen van behoorlijk bestuur zoals het vertrouwensbeginsel of zorgvuldigheidsbeginsel).

\begin{tabular}{|c|c|c|}
\hline 1. strategisch niveau & Omgevingsvisie & ambities \\
\hline 2. tactisch niveau & Beleidsnotitie & ambities \& plekken \\
\hline 3. operationeel niveau & Omgevingsplan & plekken \& regels \\
\hline
\end{tabular}

Figuur 4.2 Steenwijkerland plaats beleidsregels tussen Omgevingsvisie en Omgevingsplan in

(Steenwijkerland, 2017)

\footnotetext{
${ }^{10} \mathrm{FH}$ Kistenkas, HC Borgers, MEA Kistenkas, Recht voor de groene ruimte, 3e druk, Wageningen 2017, p. 134-137.
} 
Het gemeentelijk bestuursorgaan kan dus zelf beslissen of hij de beleidsregels in concrete gevallen toepast of juist niet. Als het een bestuursbevoegdheid is voor het college van B\&W (bijv. verlenen van vergunningen) heeft de raad er, bestuursrechtelijk gezien, niets mee te maken. De beleidsregels zijn dus zeer flexibel in toepassing (vergunningverlening) en aanpassing (bijv. bij een nieuwe samenstelling van het college van B\&W). De gemeente zou hier op gewezen zijn door de Inspiratiegids Chw van het toenmalige ministerie van I\&M.

Voor de gemeentelijke gebiedskenmerken geldt dus een drietrapsraket van omgevingsvisie, een tussenlaag van beleidsregels en het omgevingsplan. De omgevingsvisie en het omgevingsplan zijn na een formele procedure vastgesteld door de raad, terwijl de beleidsnotitie door B\&W (te allen tijde en dus ook tussentijds) kan worden aangepast en kan worden toegepast, maar ook de werking van de officiële instrumenten in concrete gevallen kan beïnvloeden. Bij toepassing van de officiële regels kan dus ook nog geput worden uit een officieuze tussenlaag van niet direct-werkende regels. Hoe dit zou kunnen gebeuren in concreto is nog niet bekend want het Omgevingsplan is nog niet van kracht, maar bestuursrechtelijk kan het zo gaan werken.

Het Omgevingsplan integreert overigens het oude bestemmingsplan buitengebied met welstand, monumentenverordening, kapverordening, ligplaatstenverordening, geurverordening, reclameverordening en andere regels. In zoverre is er dus inderdaad sprake van een verbrede reikwijdte.

Met het omgevingsplan van Steenwijkerland ontstaat een doorwerking van generiek landschapsbeleid, door de provincie Overijssel, naar een specifiek en verder uitgewerkt landschapsbeleid door de gemeente Steenwijkerland (zie figuur 4.3).

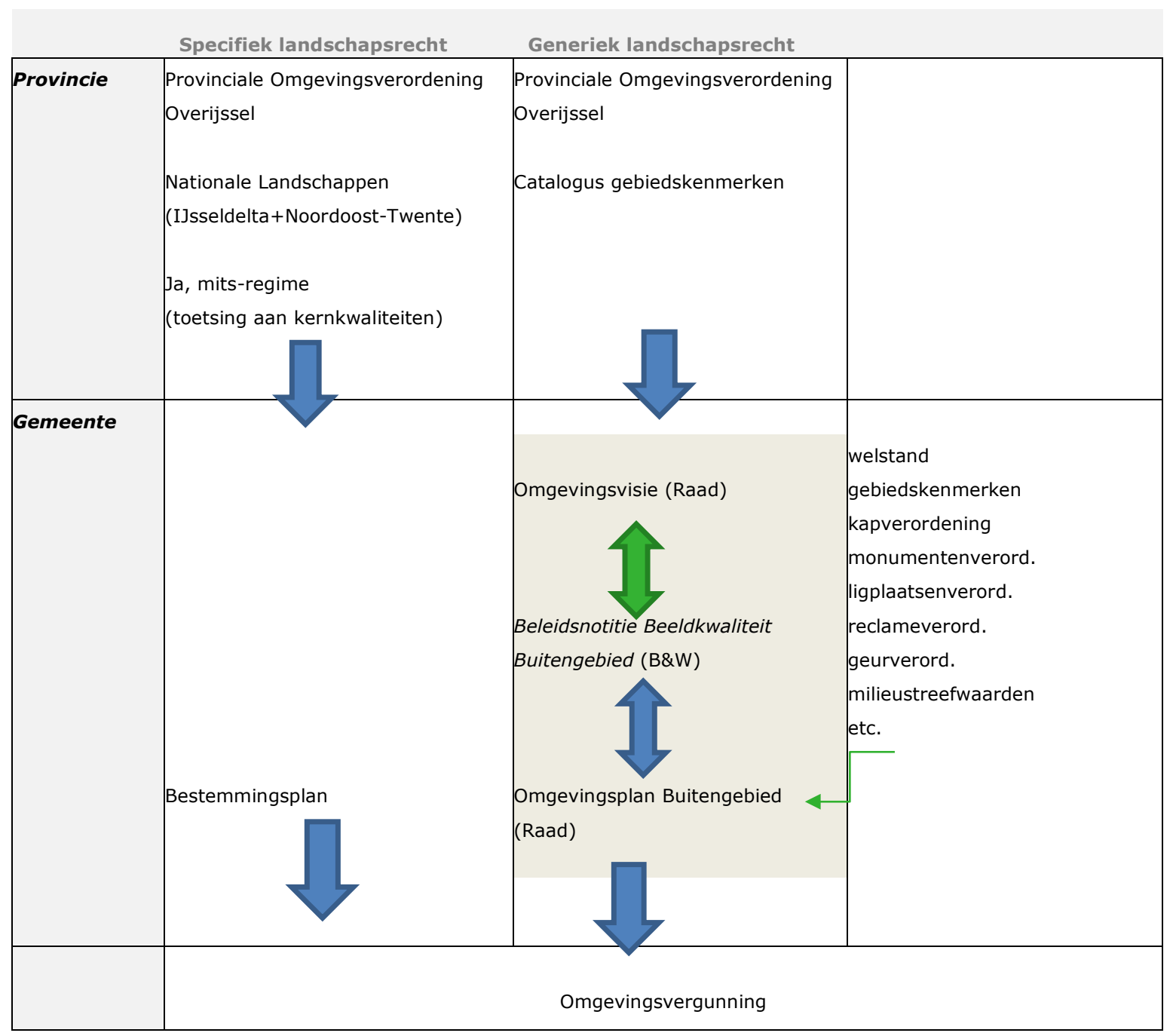

Figuur 4.3 Het generieke landschapsbeleid van de provincie Overijssel wordt door de gemeente Steenwijkerland verder uitgewerkt in hun omgevingsplan 


\section{Boodschappen voor natuur en landschap}

\section{$5.1 \quad$ Naturwetgeving verbrokkelt}

In de Omgevingswet en alle onderliggende instrumenten, worden de goed gestructureerde artikelen van de Wet natuurbescherming uiteengetrokken. De bepalingen kunnen terecht komen in de Omgevingswet zelf, in het Besluit algemene regels, in het Besluit kwaliteit leefomgeving, in de Aanvullingswet natuur, in het Aanvullingsbesluit natuur en in de Aanvullingsregeling natuur. Dus ook de Aanvullingswet natuur is kaderstellend, omdat inhoudelijke normen in de uitvoeringsregelgeving zullen komen, maar de ontwerpteksten voor deze laatst twee ontbreken nog. Hierdoor ontbreekt het aan een overzicht van de uiteindelijke uitwerking. Hierdoor kan ook (nog) niet goed worden aangegeven of sprake zal zijn van een beleidsneutrale omzetting (er zijn al aanwijzingen dat dit voor een aantal aspecten niet het geval is). Zoals Backes en Freriks (2017) in hun overzichtelijke artikel vermelden, stellen zij dat de inpassing van de natuurbeschermingswetgeving in de Omgevingswet gebeurt in hapjes en brokjes, waardoor het op dit moment onmogelijk is om het natuurbeschermingsrecht in het geheel in samenhang te bekijken, waarderen en becommentariëren. Doorgronding van het natuurbeschermingsrecht wordt in de toekomst dus veel onoverzichtelijker en ingewikkelder. Een totaalplaatje van de gevolgen van de stelselherziening omgevingsrecht voor natuur ontbreekt.

Backes en Freriks (2017) geven verschillende voorbeelden van deze verbrokkeling:

- De aanwijzing van Natura 2000-gebieden komt in instructieregels van het Omgevingsbesluit.

- Vergunningsvereiste Natura 2000-gebieden en ontheffingen met betrekking tot soorten wordt geregeld via de Omgevingsvergunning.

- Het inhoudelijk beoordelingskader voor de passende beoordeling van Natura 2000-gebieden (teksten art 6.3 en 6.4 HR) komt terecht in het in Bkl.

- Vaststellen van het beheerplan wordt geregeld in Ow, maar inhoudelijke eisen beheerplan komen in instructieregels Bkl.

- Verbodsbepalingen komen via Ow terug als 'flora- en fauna-activiteit' in de Aanvullingswet natuur, welke activiteiten in het Bal nader zullen worden omschreven.

- Ook inhoudelijke toetstingskaders (regels voor verlenen/weigeren omgevingsvergunning) voor soorten staan niet in het Ow maar in het Bkl.

- De Gedragscode voor soorten wordt geregeld in AMvB (Bkl).

- Keuze van middelen bij het afwijken van verbodsbepalingen staan niet in de Aanvullingswet natuur, maar in AMvB.

\subsection{Beleidsafzwakking Natuurnetwerk Nederland}

Nu het Besluit kwaliteit leefomgeving (Bkl) definitief is en als wetgeving (een Algemene Maatregel van Bestuur onder de toekomstige Omgevingswet) het Staatsblad gehaald heeft, weten we hoe vanaf 2021 het Natuurnetwerk Nederland (NNN) beschermd gaat worden. Alles zou beleidsneutraal worden overgezet vanuit de huidige regelgeving, maar voor het NNN geldt dat niet. Soms wordt de bescherming strenger, maar soms ook juist weer niet.

In het nu nog geldende Barro (Besluit algemene regels ruimtelijke ordening) wordt het NNN (daarin nog EHS genoemd) beschermd met een redelijk streng nee, tenzij-regime, een soort habitattoets light: de wezenlijke kenmerken en waarden (de WKWs) van het gebied mogen niet significant worden aangetast, tenzij er geen alternatieven zijn, er sprake is van een groot openbaar belang en er compensatie plaatsvindt. Dat nee, tenzij-regime wordt in het BKL echter niet meer genoemd. Ook de alternatieventoets en dat groot-openbare belang vinden we niet meer terug. Provincies zijn alleen nog maar verplicht om de begrenzing en de WKWs vast te stellen en voor natuurcompensatie te zorgen. 
Dat laatste is winst want in de oude regeling was ook financiële compensatie nog juridisch acceptabel. Binnenkort zal er echter uitsluitend fysiek gecompenseerd kunnen en moeten worden, dus echte compensatie in natura. Er moet, zo staat er letterlijk: 'tijdig worden gecompenseerd, zodanig dat de kwaliteit, oppervlakte en samenhang van het natuurnetwerk behouden blijven'. Dat lijkt winst voor de natuur. Het is een aanscherping van de huidige regeling. Aan de andere kant worden provincies in hun omgevingsverordening niet meer expliciet opgedragen om daarin een nee, tenzij-beschermingsregime op te nemen. De daarbij behorende significantietoets, alternatieventoets en het groot-openbaar belang worden niet meer genoemd.

Dat betekent dat provincies dus meer vrijheid krijgen om hun NNN-toets in te richten. Het zou zelfs kunnen verworden tot een zwakkere ja, mits-toets. Het enige dat geëist wordt van het provinciale beschermingsregime is dat de regels verzekeren dat de kwaliteit en oppervlakte van het NNN niet achteruit gaan en dat nadelige gevolgen tijdig gecompenseerd worden, aldus letterlijk art. 7.8 lid 2 BKL. Dat is minder dan wat nu geëist wordt in het Barro.

Het kan gaan betekenen dat twaalf provincies het elk weer anders gaan doen en ook iedere vier jaar na politieke wisselingen in provinciale staten en gedeputeerde staten veel ruimte hebben voor veranderingen. De provinciale diversiteit en rechts(on)zekerheid valt nu nog mee omdat het Barro veel strenger en preciezer is. Dit is kennelijk losgelaten in het Bkl. Hier dus geen beloofde beleidsneutraliteit maar beleidsverandering. Eerder wellicht beleidsafzwakking.

Afgewacht moet worden of via deze zogenoemde getrapte instructieregels van Rijk (AMvB) en provincie (Omgevingsverordening) alles ook goed in het gemeentelijk omgevingsplan landt. ${ }^{11} \mathrm{Er}$ wordt al veel vrijheid gelaten aan de provincies en het is de vraag hoeveel vrijheid gemeenten op hun beurt dan weer krijgen om toch de NNN-toets te omzeilen of te doorstaan.

De Ecologische Hoofdstructuur (EHS) startte in de jaren negentig slechts als planologisch beleidsconcept zonder wettelijke borging en dus zonder juridische afdwingbaarheid. Dat veranderde pas begin jaren tien van deze eeuw met het Barro, maar met het Bkl is de juridische afdwingbaarheid van het nee, tenzij regime dus weer verminderd.

\subsection{Eenvoudig beter en duurzamer?}

Het is vooralsnog onduidelijk of de stelselherziening van het omgevingsrecht met de Omgevingswet tot betere besluitvorming zal leiden voor de dossiers natuur en landschap.

Eén van de redenen is dat er geen landelijk kader is voor integrale afweging. Een integrale afweging vindt plaats op decentraal niveau en is mede gebaseerd op door provincie of gemeente vast te leggen omgevingswaarden. Zolang deze omgevingswaarden niet bekend zijn, en dus ook niet hoe het lokale 'mengpaneel' (zie figuur 2.2) er uit ziet, is niet aan te geven hoe de integrale afweging uitpakt voor natuur en landschap. Feit is dat een deel van de in de Omgevingswet opgaande wetten uit de aard der zaak het eigen, sectorale afwegingskader behoudt. Bovendien is de Omgevingswet een raamwet, waarbij veel uitwerkingen plaatsvinden in de vier onderliggende besluiten/AMvB's. Dit maakt de uitwerking in de praktijk toch (weer) complex. Al met al is hierdoor onduidelijk hoeveel ruimte geboden wordt aan een duurzame afweging.

Zo vraagt Zwalve-Erades (2015) zich af of duurzame ontwikkeling juist niet belemmerd wordt doordat bedrijven 'verstrikt raken in een web van strategische plannen, abstract geformuleerde zorgplichten en globale regels voor activiteiten en dat (vermeende) onderlinge tegenstrijdigheden en discussies met stakeholders leiden tot verstarring'.

\footnotetext{
${ }^{11}$ R Frins, De bescherming van het NNN onder de Ow, Tijdschrift Omgevingsrecht 2018, p. 4-12.
} 
Ook door de VNG ${ }^{12}$ worden vraagtekens geplaatst bij het integrale afweging: "Bestuurlijke afwegingsruimte is hartstikke mooi, maar je moet die afwegingen wel maken. Daarvoor moet je al je beleid screenen, bedenken welke gemeente je wilt zijn en dat doorvertalen naar een visie. Daar is veel kennis en capaciteit voor nodig, bovendien is nu nog lastig te overzien wat de nieuwe werkwijze van ambtenaren vraagt. Het positieve Omgevingswetverhaal verdient nuancering."

Van 't Foort en Kevelam (2015) concluderen dat de Omgevingswet wel een stimulans biedt voor duurzaamheid en integrale afweging, maar onvoldoende waarborgen om realisatie hiervan te garanderen. Zij wijzen daarbij o.a. op het feit dat er te weinig waarborgen zijn om de omgevingswaarden te behalen en de onduidelijke invulling van het begrip 'fysieke leefomgeving' waardoor ook niet duidelijk is hoe belangen geprioriteerd moeten worden.

\subsection{Meer of juist minder participatie voor natuur en landschap}

Voor participatie van belanghebbenden onder de Omgevingswet is een tegenstelling zichtbaar tussen hetgeen de wet beoogd (meer participatie) en hetgeen deskundigen voorzien (informeren van partijen en proces hoe participatie vorm te geven), zie paragraaf 2.5. De vraag is hoe stakeholders betrokken worden bij de dossiers natuur en landschap. In de praktijk lijkt het dat provincies bij het opstellen van natuurvisies de verschillende belangengroepen betrekken via groene tafels, manifestpartners etc.

(Folkert \& Boonstra, 2017). Van 't Foort en Kevelam (2015) merken op dat het voor burgers lastiger is geworden om bij de rechter hun gelijk te halen.

Ten eerste kan men alleen bezwaar en beroep instellen als men belanghebbende is, met de invoering van het relativiteitsbeginsel in het bestuursrecht. Hiermee moet men belanghebbende zijn wil men kunnen appelleren tegen een besluit. Hiermee is de gang naar de rechter ingeperkt voor bijvoorbeeld natuur- en milieuorganisaties die in het algemeen belang opereren.

Ten tweede, zo stellen Van 't Foort en Kevelam worden steeds meer activiteiten gereguleerd via algemene regels in plaats van via toetsing en vergunningverlening. Hiermee, zo stellen zij, verdwijnt de mogelijkheid om bezwaar en beroep aan te tekenen en verdwijnt dus de (bestuursrechtelijke) rechtsbescherming. Bij een projectbesluit moet het bevoegd gezag stakeholders zoals burgers en bedrijven, betrekken bij de voorbereiding. Daarbij kan een adviesgroep worden ingesteld, indien er discussie is over het al dan niet opvolgen van een voorgesteld initiatief door deze stakeholders. Ook de mogelijkheid van het vervallen van het indienen van een zienswijze bij het opstellen van een Milieueffectrapportage (MER) kan gevolgen hebben voor participatie.

\footnotetext{
${ }^{12}$ http://m.binnenlandsbestuur.nl/nieuws/wetgevingsproces-omgevingswet-frustreert.119026.lynkx
} 



\section{Literatuur}

Backes., Ch. W. en A.A. Freriks (2017). Gebiedsbescherming en soortenbescherming in de Aanvullingswet natuur Omgevingswet (februari 2017, Tijdschrift voor Omgevingsrecht) Natuur \& Milieu, 2017 Brief aan de afdeling advisering Rvs (20 juli 2017)

Bekker, R \& C. Nikkels (2015). Nadere Analyse Informatiehuis Natuur. Interprovinciaal Overleg, Den Haag.

Bosma, W.J. (2014). Omgevingswaarde en instructieregels - een combinatie van flexibiliteit en interbestuurlijke spanningen. Milieu en Recht, 119: 601-609.

Broek, A. van den, A. Steenbekkers, P. van Houwelingen \& K. Putters (2016). Niet buiten de burger rekenen. Sociaal en Cultureel Planbureau, Den Haag.

Bugel Hajema (2017). Bestemmingsplan buitengebied Steenwijkerland. Bugel Hajema, Assen.

Commissie Versnelling Besluitvorming Infrastructurele Projecten (2008). Sneller en beter: Advies Commissie Versnelling Besluitvorming Infrastructurele Projecten. Commissie Elverding, Den Haag.

Folkert, R. \& F. Boonstra (2017). Lerende evaluatie van het Natuurpact: Naar nieuwe verbindingen tussen natuur, beleid en samenleving. Den Haag: Planbureau voor de Leefomgeving, Wageningen: Wageningen University \& Research

Folkert, R. \& H. Diederen et al. (2013). Milieueffectentoets wetsvoorstel Omgevingswet, Den Haag: PBL.

Foort, S. van 't en J. Kevelam (2015). Het waarborgen van duurzaamheid in de Omgevingswet. In: Tijdschrift voor Omgevingsrecht 2015 (1).

Graaf, K.J. de, F.M. Platjouw, H.D. Tolsma (2017). The future Dutch Environment and Planning Act in light of the ecosystem approach, Ecosystem Services 2017

Grinlinton, D (2016). Horizontal and vertical integration of sustainability into policymaking, planning and implementation of renewable energy projects. The New Zealand model, In: V. Mauerhofer (red.), Legal aspects of sustainable development, Springer, p. 423-448.

Groene Organisaties (2017). Reacties op de Aanvullingswet natuur (20 januari 2017)

Hajer, M. (2011). De energieke samenleving. Planbureau voor de leefomgeving, Bilthoven.

I\&M (2014). Naar de Laan van de Leefomgeving: Bouwsteen voor een digitaal stelsel Omgevingswet. Ministerie van Infrastructuur en Milieu, Den Haag.

I\&M (2016). Brief 23 juni 2106. Kamerstuk 33962 nr. 188. Ministerie van Infrastructuur en Milieu, Den Haag.

I\&M (2017). Inspiratiegids bestemmingsplan met verbrede reikwijdte. Den Haag, Ministerie van Infrastructuur en Milieu.

Kajaan, M. (2016). Aanvullingswet Natuur in de Omgevingswet. Bron: http://www.omgevingsweb.nl/nieuws/aanvullingswet-natuur-in-de-omgevingswet

Kistenkas, F.H. \& I.M. Bouwma (2017). Barriers for the ecosystem services concept in European water and nature conservation law, Ecosystem Services 2017.

Kistenkas, F.H., H.C. Borgers en M.E.A. Kistenkas (2017). Recht voor de groene ruimte, Wageningen: Wageningen Academic Publishers.

Ministerie van I\&M juni (2014). Brochure Aan de slag met de Omgevingswet. Ministerie van I\&M, Den Haag

Ministerie van I\&M (2017a). Ontwerpbesluit Kwaliteit Leefomgeving van 1 juli 2016, inclusief Nota van Toelichting en artikelsgewijze toelichting

Ministerie van I\&M (2017b) Ontwerp Omgevingsbesluit van 1 juli 2016, inclusief Nota van Toelichting en artikelsgewijze toelichting 
Nijmeijer, A.G.A. (2015). Omgevingswet I: het wetsvoorstel geamendeerd. Instituut voor Bouwrecht, http://www.ibrtracker.nl/docs/articles/2015/augustus/tbr-2015-122\#fnt1

OCW (2015). Dienstverlening versterken met het Informatiehuis Cultureel Erfgoed Versie 0.50. Ministerie van Onderwijs, Cultuur en Wetenschap, Den Haag.

RLI (2015). Vernieuwing omgevingsrecht: maak de ambities waar. Raad voor de Leefomgeving en Infrastructuur, Den Haag.

Staatsblad (2016). Omgevingswet, zoals gepubliceerd in het Staatsblad op 23 maart 2016

Steenwijkerland (2017). Beleidsnota Beeldkwaliteit Buitengebied Steenwijkerland 2017. Gemeente Steenwijkerland, Steenwijk.

Stibbe Advocaten (2014). Milieueffectrapportage in de Omgevingswet. In: Bundel Op weg naar de Omgevingswet http://www.estibbe.com/pgo/documenten/Bundel_Omgevingswet.pdf\#page=78

TK (2013-2014). Memorie van Toelichting op de Omgevingswet, Tweede Kamer, vergaderjaar 2013-2014, $33962, \mathrm{nr} .3$.

TK (2016). Bijlage ${ }^{13}$ bij Kamerbrief met aanvullende informatie AMvB's Omgevingswet d.d. 10 oktober 2016.

Zwalve-Erades, J. (2015). De nieuwe Omgevingswet en duurzaamheid.

http://www.omgevingsweb.nl/nieuws/de-nieuwe-omgevingswet-en-duurzaamheid

\footnotetext{
${ }^{13}$ Bijlage 1. Vergelijking normhoogtes BkI milieudomein en Bijlage 2. Decentrale omgevingswaarden
} 


\section{Verantwoording}

De tekst werd beoordeeld door Joep Dirkx (WOT Natuur \& Milieu, WUR) en Alexandra Tisma (Planbureau voor de Leefomgeving, PBL). Voorts werden de eindconclusies op 16 april 2018 voorgelegd en bediscussieerd tijdens een lunchdebat bij het PBL in Den Haag met als sprekers Frank van Dam (PBL) en Fred Kistenkas (WUR). De illustratie van paragraaf 4.6 (Illustratie Steenwijkerland: uitwerking van landschapsbeleid) is mede gebaseerd op een interview van Wim Nieuwenhuizen en Fred Kistenkas op 17 november 2017 in Steenwijk met Joost Huizing, Kwartiermaker invoering Omgevingswet bij de gemeente Steenwijkerland. 



\section{Bijlage 1 PBL-rapport omgevingswet - Folkert en Diederen, 2013}

In dit PBL-rapport wordt gesteld dat met het wetsvoorstel Omgevingswet per saldo de risico's voor de milieu- en natuurbescherming groter waren dan de kansen. Dit komt door de manier waarop de extra ruimte voor ontwikkelingen in het wetsvoorstel wordt vormgegeven: "Het is op verschillende manieren mogelijk om af te wijken van de milieu- en natuurregelgeving. Dit kan onder andere via het ontwikkelingsgebied, de experimenteerbepaling en de gelijkwaardigheidsbepaling. "

Ook geven zij aan dat het wetsvoorstel Omgevingswet via het projectbesluit nog een aantal andere mogelijkheden biedt om de regelgeving voor de projecten van het Rijk en de provincie te versoepelen. Het projectbesluit biedt volgens Folkert en Diederen de meeste flexibiliteit om van de milieu- en natuurregelgeving af te wijken, terwijl het hierbij gaat om grote en complexe projecten als snelwegen, windmolenparken en waterbergingsgebieden.

Ook geven de onderzoekers aan dat door de beperkingen aan de procedure voor de milieueffectrapportage ten aanzien van alternatievenonderzoek.

Bovendien plaatsen de onderzoekers een kanttekening bij het feit dat in het wetsvoorstel gemeenten niet verplicht zijn om een integrale omgevingsvisie op te stellen voor de lange termijn.

In de Memorie van antwoord Omgevingswet gaat de Minister van I\&M in op twee resultaten van dit onderzoek.

- Ten aanzien van het projectbesluit stelt zij dat de regering het standpunt van de onderzoekers niet dat de invulling van het projectbesluit tot extra risico's voor natuur en milieu zou kunnen leiden, niet deelt. Van belang daarbij is dat regels die door het Rijk en de decentrale overheden worden gesteld ter bescherming van natuur en milieu ook van toepassing zijn op het projectbesluit. Maar stelt de Minister even verder, het buiten toepassing laten van decentrale regels kan niet zomaar. Dat is begrensd tot die situaties waarin dat nodig is 'om dringende redenen'. Dat betekent dat het projectbesluit ook aan deze decentrale regels moet voldoen, tenzij het project anders niet binnen redelijke grenzen kan worden gerealiseerd.

Opmerking Mirjam: de vraag is natuurlijk wat dan 'dringende redenen' en 'redelijke grenzen' zijn. Zullen dringende redenen 'dwingende redenen van groot openbaar belang' zijn in analogie met de Habitatrichtlijn? En vallen onder redelijke grenzen de vereisten vanuit de Habitatrichtlijn voor alternatievenonderzoek? Hier lijkt toch een escape te zitten voor grote projecten!

- Ten aanzien van de procedure milieueffectrapportage geeft de minister aan dat conclusie van de onderzoekers, over de relatie tussen plan-mer/project-mer mogelijk berust op een misverstand over de werking van artikel 16.52, derde lid. Hierdoor onderkennen deze onderzoekers niet de waarborgen die in het wetsvoorstel zijn opgenomen over alternatievenonderzoek. De minister licht toe dat in dat is bepaald dat als voor een voorgenomen project in een plan een locatie (zoals een tracé), is aangewezen en voor dat plan een plan-mer is gemaakt, herhaling van deze locatiekeuze bij het alternatievenonderzoek voor het project niet nodig is (de als-dan-bepaling). In andere gevallen is alternatieven-onderzoek wel vereist.

Opmerking Mirjam: is hiermee idd het risico voor natuur verdwenen?

Wat betreft het feit dat een omgevingsvisie niet verplicht is voor gemeenten, is deze verplichting wel opgenomen in het voorstel van Wet zoals aangenomen door de TK en EK (gewijzigd artikel 3.1 lid 1). 



\section{Verschenen documenten in de reeks Technical reports van de Wettelijke Onderzoekstaken Natuur}

\& Milieu vanaf 2018

WOt-technical reports zijn verkrijgbaar bij het secretariaat van Unit Wettelijke Onderzoekstaken Natuur \& Milieu te Wageningen. T 0317 - 4854 71; E info.wnm@wur.nl

WOt-technical reports zijn ook te downloaden via de website www.wur.nl/wotnatuurenmilieu.

113 Arets, E.J.M.M., J.W.H van der Kolk, G.M. Hengeveld, J.P. Lesschen, H. Kramer, P.J. Kuikman \& M.J. Schelhaas (2018). Greenhouse gas reporting for the LULUCF sector in the Netherlands. Methodological background, update 2018

114 Bos-Groenendijk, G.I. en C.A.M. van Swaay (2018). Standaard Data Formulieren Natura 2000gebieden; Aanvullingen vanwege wijzigingen in Natura 2000-aanwijzingsbes/uiten

115 Vonk, J. , S.M. van der Sluis, A. Bannink, C. van Bruggen, C.M. Groenestein, J.F.M. Huijsmans, J.W.H. van der Kolk, L.A. Lagerwerf, H.H. Luesink, S.V. Oude Voshaar \& G.L. Velthof (2018.) Methodology for estimating emissions from agriculture in the Netherlands - update 2018. Calculations of $\mathrm{CH} 4, \mathrm{NH} 3, \mathrm{~N} 2 \mathrm{O}, \mathrm{NOx}$ PM10, PM2.5 and CO2 with the National Emission Model for Agriculture (NEMA)

116 IJsseldijk, L.L., M.J.L. Kik, \& A. Gröne (2018). Postmortaal onderzoek van bruinvissen (Phocoena phocoena) uit Nederlandse wateren, 2017. Biologische gegevens, gezondheidsstatus en doodsoorzaken.

117 Mattijssen, T.J.M. \& I.J. Terluin (2018). Ecologische citizen science; een weg naar grotere maatschappelijke betrokkenheid bij de natuur?

118 Aalbers, C.B.E.M., D. A. Kamphorst \& F. Langers (2018). Bedrijfs- en burgerinitiatieven in stedelijke natuur. Hun succesfactoren en knelpunten en hoe de lokale overheid ze kan helpen slagen.

119 Bruggen, C. van, A. Bannink, C.M. Groenestein, J.F.M. Huijsmans, L.A. Lagerwerf, H.H. Luesink, S.M. van der Sluis, G.L. Velthof \& J. Vonk (2018). Emissies naar lucht uit de landbouw in 2016. Berekeningen met het model NEMA

120 Sanders, M.E., F. Langers, R.J.H.G. Henkens, J.L.M. Donders, R.I. van Dam, T.J.M. Mattijssen \& A.E. Buijs (2018). Maatschappelijke initiatieven voor natuur en biodiversiteit; Een schets van de reikwijdte en ecologische effecten en potenties van maatschappelijke initiatieven voor natuur in feiten en cijfers

121 Farjon, J.M.J., A.L. Gerritsen, J.L.M. Donders, F. Langers \& W. Nieuwenhuizen (2018). Condities voor natuurinclusief handelen. Analyse van vier praktijken van natuurinclusief ondernemen

122 Gerritsen, A.L., D.A. Kamphorst \& W. Nieuwenhuizen (2018). Instrumenten voor maatschappelijke betrokkenheid. Overzicht en analyse van vier cases
123 Vullings, L.A.E., A.E. Buijs, J.L.M. Donders, D.A. Kamphorst, H. Kramer \& S. de Vries (2018). Monitoring van groene burgerinitiatieven; Analyse van de resultaten van een pilot en nulmeting in vier gemeenten

124 Boonstra, F.G., Th.C.P. Melman, W. Nieuwenhuizen \& A. Gerritsen (2018). Aanpak evaluatie stelselvernieuwing agrarisch natuurbeheer; Uitgangspunten en opties voor een beleidsevaluatie

125 Vullings, L.A.E., A.E. Buijs, J.L.M. Donders \& D.A Kamphorst (2018). Monitoring van groene burgerinitiatieven; Methodiek, indicatoren en ervaring met pilot en nulmeting.

126 Beltman, W.H.J., M.M.S. ter Horst, P.I. Adriaanse \& A. de Jong (2018). Manual for FOCUS_TOXSWA v5.5.3 and for expert use of TOXSWA kernel v3.3; User's Guide version 5

127 Van der Heide, C.M. \& M.M.M. Overbeek (2018). Natuurinclusief handelen en ondernemen. Scopingstudie 'Bedrijven, economie en natuur'

128 Langers, F. (2018). Recreatie in groenblauwe gebieden; Actualisatie van CLO-indicator 1258 (Bezoek aan groenblauwe gebieden) op basis van data van het Continu Vrijetijdsonderzoek uit 2015

129 Glorius, S.T., I.Y.M. Tulp, A. Meijboom, L.J. Bolle and C. Chen (2018). Developments in benthos and fish in an area closed for human use in the Dutch Wadden Sea; 2002-2016 closed area Rottum

130 Kamphorst, D.A \& T.J.M. Mattijssen (2018) Scopingstudie Vermaatschappelijking van natuur. Een overzicht van onderzoek bij Wageningen Universiteit \& Research voor het Planbureau voor de Leefomgeving en het ministerie van Landbouw, Natuur en Voedselkwaliteit

131 Breman, B.C., T.J.M. Mattijssen \& T.M. Stevens (2018). Natuur 2.0. Het natuurdebat op social media.

132 Vries, S. de \& W. Nieuwenhuizen (2018) HappyHier: hoe gelukkig is men waar?; Gegevensverzameling en bepaling van de invloed van het type grondgebruik op hoe gelukkig men zich voelt, deel II

133 Kistenkas, F.H., W. Nieuwenhuizen, D.A. Kamphorst \& M.E.A. Broekmeyer (2018). Natuur en landschap in de Omgevingswet. 



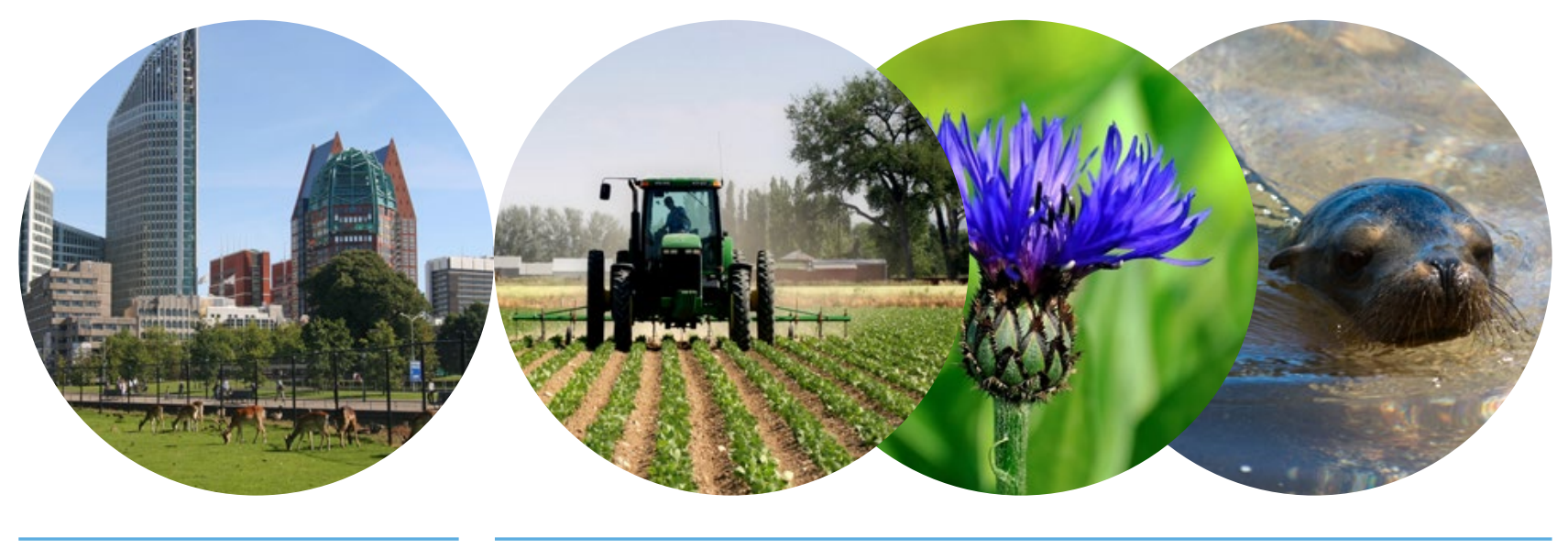

Thema Periodieke

Verkenning Natuurbeleid

Postbus 47

6700 AA Wageningen

T (0317) 485471

E info.wnm@wur.nl

ISSN 2352-2739

www.wur.nl/wotnatuurenmilieu
De missie van Wageningen University \& Research is 'To explore the potential of nature to improve the quality of life'. Binnen Wageningen University \& Research bundelen 9 gespecialiseerde onderzoeksinstituten van Stichting Wageningen Research en Wageningen University hun krachten om bij te dragen aan de oplossing van belangrijke vragen in het domein van gezonde voeding en leefomgeving. Met ongeveer 30 vestigingen, 5.000 medewerkers en 10.000 studenten behoort Wageningen University \& Research wereldwijd tot de aansprekende kennisinstellingen binnen haar domein. De integrale benadering van de vraagstukken en de samenwerking tussen verschillende disciplines vormen het hart van de unieke Wageningen aanpak. 